\title{
Identification of differentially expressed Atlantic salmon miRNAs responding to salmonid alphavirus (SAV) infection
}

Rune Andreassen ${ }^{1 *} \mathbb{D}$, Nardos Tesfaye Woldemariam¹, Ine Østråt Egeland', Oleg Agafonov², Hilde Sindre ${ }^{3}$ and Bjørn Høyheim ${ }^{4}$

\begin{abstract}
Background: MicroRNAs (miRNAs) control multiple biological processes including the innate immune responses by negative post-transcriptional regulation of gene expression. As there were no studies on the role(s) of miRNAs in viral diseases in Atlantic salmon, we aimed to identify miRNAs responding to salmonid alphavirus (SAV) infection. Their expression were studied at different time points post infection with SAV isolates associated with different mortalities. Furthermore, the genome sequences of the identified miRNAs were analysed to reveal putative cisregulatory elements, and, finally, their putative target genes were predicted.

Results: Twenty differentially expressed miRNAs (DE miRNAs) were identified. The expression of the majority of these increased post infection with maximum levels reached after the viral load were stabilized or decreasing. On the other hand, some miRNAs (e.g. the miRNA-21 family) showed decreased expression at the early time points post infection. There were significant differences in the temporal expression of individual miRNA associated with different SAV isolates. Target gene prediction in SAV responsive immune network genes showed that seventeen of the DE miRNAs could target 24 genes (e.g. IRF3, IRF7). Applying the Atlantic salmon transcriptome as input 28 more immune network genes were revealed as putative targets (e.g. IRF5, IRF4). The majority of the predicted target genes promote inflammatory response. The upstream sequences of the miRNA genes revealed a high density of cis-regulatory sequences known as binding sites for immune network transcription factors (TFs). A high expression in the late phase could therefore be due to increased transcription promoted by immune response activated TFs. Based on the in silico target predictions, we discuss their putative roles as early promotors or late inhibitors of inflammation. We propose that the differences in expressions associated with different SAV isolates could contribute to their differences in mortality rates.
\end{abstract}

Conclusions: This study represents the first steps in exploring miRNAs important in viral-host interaction in Atlantic salmon. We identified several miRNAs responding to SAV infection. Some likely to prohibit harmful inflammation while other may promote an early immune response. Their predicted functions need to be validated and further studied in functional assays to fully understand their roles in immune homeostasis.

Keywords: miRNA, Virus, Atlantic salmon, Innate immune response

\footnotetext{
* Correspondence: Rune.Andreassen@hioa.no

'Department of Pharmacy and Biomedical and Laboratory Sciences, Faculty

of Health Sciences, Oslo and Akershus University College of Applied

Sciences, Pilestredet 50, N-0130 Oslo, Norway

Full list of author information is available at the end of the article
}

(c) The Author(s). 2017 Open Access This article is distributed under the terms of the Creative Commons Attribution 4.0 International License (http://creativecommons.org/licenses/by/4.0/), which permits unrestricted use, distribution, and reproduction in any medium, provided you give appropriate credit to the original author(s) and the source, provide a link to the Creative Commons license, and indicate if changes were made. The Creative Commons Public Domain Dedication waiver (http://creativecommons.org/publicdomain/zero/1.0/) applies to the data made available in this article, unless otherwise stated. 


\section{Background}

MicroRNAs (miRNAs) are important regulators of gene expression at the post transcriptional level. Pre-miRNAs are transported from the nucleus and processed into two small mature miRNAs (5p and 3p) that usually are 20$24 \mathrm{nt}$ in length. The mature miRNAs are incorporated into the miRNA-induced silencing complex (miRISC). Their function in miRISC are to recognize the target genes by partial base pairing to their transcripts $[1,2]$. Due to their role as regulators of gene networks, the majority of miRNAs are highly conserved in vertebrates, but there are also miRNAs that seem to be species specific [3-5].

MiRNAs are involved in regulation of almost all cellular processes including development, growth, maintenance of tissue-specific functions and apoptosis [6-9]. Some miRNAs are also important key regulators of normal immune function and immune responses [10, 11]. Several studies in vertebrates have shown that some miRNAs play important roles in the virus-host interaction following virus infection. Viruses may themselves encode miRNAs (viral miRNAs) that may be involved in cellular reprogramming to promote a cellular environment favorable to viral life cycle. To achieve such an advantage to viral life cycle other viral factors may also repress or induce expression of host miRNAs (cellular miRNAs) [12]. On the other hand, altered expression of cellular miRNAs may also be a consequence of host responses to viral infection where the hosts utilize miRNAs as part of its defense mechanisms $[13,14]$. Some of the affected cellular miRNAs have been shown to regulate genes in gene networks associated with innate immune response [15]. The modulation of cellular miRNAs following virus infection could therefore be favorable for either the virus or the host depending on the function of the particular miRNA modulated and the direction of the change in expression [12, 13, 16-18]. As demonstrated in some studies, detailed knowledge about miRNAs, their target genes and the disease mechanisms may potentially lead to the discovery of new diagnostic markers [19] and novel therapeutic approaches [20].

The role of miRNAs following RNA virus infection is less well studied in teleosts than in higher vertebrates. However, some recent studies of economically important teleost species have identified miRNAs responding to viral infection (e.g. [21-24]). We are particularly interested in miRNAs that affect disease development following viral infection in the economically important aquaculture species Atlantic salmon (Salmo salar L.). Recently, mature miRNAs and their corresponding miRNA genes were characterized in Atlantic salmon [25, 26], and RT-qPCR methods to study the expression of single miRNAs have been validated [27]. So far, no studies of the putative role(s) of miRNAs in viral disease have been carried out in
Atlantic salmon, but one study in rainbow trout (Onchorhyncus mykiss) identified miRNAs associated with Viral hemorrhagic septicaemia virus infection [28]. A better understanding of the particular miRNAs showing a change in expression levels, the direction of change (reduced or increased expression) and prediction of their target genes could provide knowledge on the particular role the modulated miRNAs have and which gene regulatory networks are affected.

Salmonid alphavirus (SAV), a member of the genus Alphavirus, family Togaviridae, is a spherical, enveloped, single-stranded positive-sense RNA virus of approximately 60-70 $\mathrm{nm}$ in diameter with a $12 \mathrm{~kb}$ genome. Pancreas disease (PD) in Atlantic salmon and sleeping disease (SD) in Rainbow trout are caused by infection with SAV [29]. Six SAV subtypes (1-6) have been identified based on the nucleic acid sequences encoding proteins E2 and nsP3 [30]. Two of these, SAV2 and SAV3 have been reported in Norway [31]. Outbreaks of PD leads to increased mortality, reduced growth, affect feed conversion and eventually lead to low product quality. Histological examination usually reveals complete loss of exocrine pancreatic tissue, cardiac myocytic necrosis and inflammation, and degeneration and/or inflammation of skeletal muscle. PD outbreaks leads to large economic losses and is a major concern in the Atlantic salmon aquaculture. A recent challenge study using Norwegian SAV isolates has demonstrated that fish infected with SAV3 have higher mortality than those infected with SAV2. In addition, significant differences in mortality within the SAV3 genotype was observed. The cause for such differences in mortality is unknown $[29,32]$.

The aim of this study was to identify cellular miRNAs that are differentially expressed (DE miRNAs) following infection with SAV. The expression of DE miRNAs was studied in samples from fish infected by one SAV2 isolate (SAV2-i1) as well as samples from fish infected with two isolates of SAV3 with diverging mortality (SAV3-i4 and SAV3-i6) [32]. Expression of DE miRNAs was measured in each SAV group at three time points post virus challenge. This allowed us to identify miRNAs responding to SAV infection, to study their expression following viral infection by each of the three SAV isolates, and explore whether there were any associations between viral load and miRNA expression. The upstream genome sequences of the differentially expressed miRNA genes were studied in order to identify conserved cis-regulatory sequences associated with genes responding to innate immune responses, and, finally, the sequences of the mature DE miRNAs were used to predict their putative target genes. These in silico predictions could further contribute to reveal the particular role of the DE miRNAs in the host-virus interaction. 


\section{Results}

RT-qPCR analyses of SAV in cardiac tissue materials

The 98 cardiac tissue samples from controls and fish challenged with SAV2-i1, SAV3-i4 and SAV3-i6 collected at week 1-4 post onset of challenge experiment (poc) were successfully analysed for SAV by RT-qPCR. All eight control samples and the nine samples collected at week 1 poc were SAV negative $(\mathrm{Ct}>45)$. Among the samples collected at week 2 poc, five of the nine samples from fish challenged with SAV2-i1 were SAV positive (55\%), eight of the nine fish challenged with SAV3-i4 was SAV positive (89\%) while all nine fish challenged with SAV3-i6 were SAV positive. All other samples collected at week 3 and 4 poc were SAV positive. Figure 1 illustrates the changes in viral load (assessed by measurements of $\mathrm{Ct}$ ) in controls and all SAV groups at the four time points (including only the SAV positive samples at week 2 poc).

The results were in agreement with findings in Taksdal et al [32]. In Taksdal's study all controls were negative $(\mathrm{Ct}>45)$, while at week 2 poc there were $63 \%$ SAV positive fish in the SAV2-i1 group, 88\% SAV positive fish in the SAV3-i4 group and 99\% SAV positive fish in the SAV3-i6 group while all fish from week 3 and 4 poc were SAV positive.

Comparison of $\mathrm{Ct}$ values in the SAV positive samples from each of the SAV groups indicated large increases in viral loads from week 2 to week 3 poc. The changes were less pronounced from week 3 to week 4 poc where the obtained $\mathrm{Ct}$ values indicated no change in virus load in the SAV3-i4 group, a small increase in the SAV2-i1 group and a small decrease in the SAV3-i6 group. The comparisons of $\mathrm{Ct}$ values in the SAV positive samples showed no significant differences at week 2 poc. However, a number of samples were SAV negative at week 2 poc, and most of these were from the SAV2-i1 group. This indicated that the time needed for infection by cohabitation was somewhat longer in the SAV2-i1 group. Ct measurements at week 3 poc did show significant differences $(p<0,05)$ between all three SAV groups (Fig. 1). These Ct-measurements at week 3 poc indicate an approximately ten times higher viral load in the SAV3-i6 group than in the SAV3-i4 group, while there was about seventeen times higher viral load in the SAV3-i4 group than in the SAV2-i1 group. Measurements at week 4 poc revealed smaller differences in $\mathrm{Ct}$ values, and only the difference between the SAV2-i1 group and the SAV3-i4 group was significant.

\section{Identification of DE miRNAs following SAV infection Deep sequencing and identification of DE miRNAs by DESeq2 analysis}

Total RNA was successfully extracted from 98 cardiac samples, and six of these were subsequently used for small RNA deep sequencing analysis. These six samples were from two groups; three healthy individuals (control group samples) and three individuals infected with SAV3-i4 (the SAV isolate associated with highest mortality rate in Taksdal et al [32]) collected at week 4 poc (see Materials and Methods). The samples were successfully

Ct-values

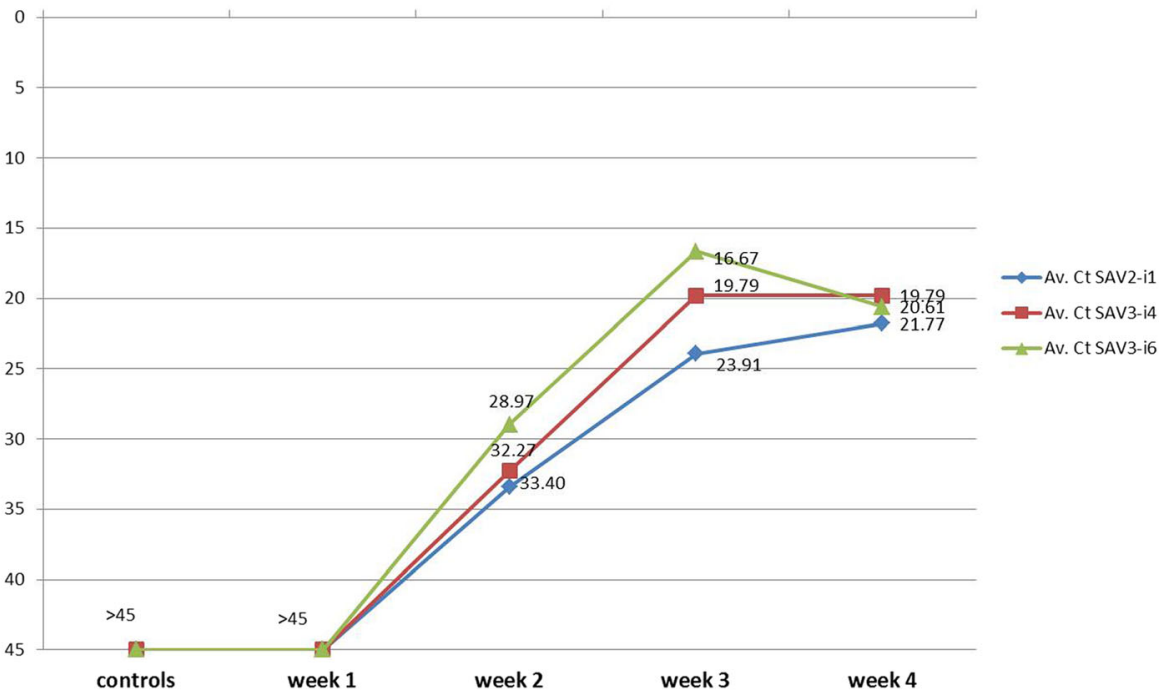

Fig. 1 Shows the increase in viral loads assessed by RT-qPCR. The mean Ct-values are given for each of the three groups challenged with SAV2-i1 (blue), SAV3-i4 (dark orange) or SAV3-i6 (green) at week 1-4 poc. The controls are the SAV negative healthy fish sampled at the initiation of the challenge trial (Ct values $>45$ ). At week 1 poc all samples were SAV negative. At week 2 poc the plot show results from only those samples that were SAV positive. All fish sampled at week 3 and 4 poc were SAV positive 
subjected to next generation sequencing using Illumina Genome Analyzer IIx sequencing platform as described in Materials and Methods. Quality control by FASTQC showed good sequence quality and similar size distributions in all samples. The results from deep sequencing including number of size filtered and adapter trimmed reads, and reads mapped as ssa-miRNAs in each sample are summarized in Additional file 1. Two out of the six samples had a number of reads recovered as miRNAs less than one million. We can not rule out that this may have affected the sensitivity to detect smaller fold changes in low expressed miRNAs. All results have been submitted to the NCBI SRA data base (Genbank SRP048613). Genbank accession numbers to the individual samples are SRR3928621 and from SRR3928623 to SRR3928627.

Reads were successfully mapped as Salmo salar miRNAs (ssa-miRNAs) by use of Novoalign (http://www.novocraft.com/products/novoalign/) that aligned reads to a reference miRNAome consisting of the mature $5 p$ and $3 p$ sequences of all known Atlantic salmon miRNAs [25, 26]. The mapped miRNAs along with their read counts were used as input in DESeq2 to reveal differences in relative expression of miRNAs by comparing samples from the group of healthy controls with the SAV3-i4 infected group (see Materials and Methods and [33]). This revealed 20 mature miRNAs that were differentially expressed in the SAV3-i4 group. Eighteen of the miRNAs showed increased expression, while two showed decreased expression. Table 1 shows all miRNAs differentially expressed and the magnitude of the change. Adjusted p-values (Benjamini-Hochberg procedure) with 0.1 as cut-off for significance are given along with the identity of the mature DE miRNAs. The eighteen DE miRNAs that revealed increased expression were ssa-miR-462a-5p and 3p, ssamiR-462b-5p, ssa-miR-731-5p and 3p, ssa-miR-146b-5p, ssa-miR-146a-3p, ssa-miR-146a-3-3p, ssa-miR-21a-1-3p, ssa-miR-21a-2-3p, ssa-miR-21b-3p, ssa-miR-181c-5p, ssamiR-223-5p, ssa-miR-1338-3p, ssa-miR-155-5p, ssa-miR92a-3-5p, ssa-miR-7132-5p and 3p. The expressions of these miRNAs were from approximately $3 \mathrm{x}$ to $19 \mathrm{x}$ higher in the SAV3-i4 infected group. Two miRNAs, ssa-miR-734-3p and ssa-miR-2188-3p, revealed decreased expression which was approximately $4 \mathrm{x}$ (ssamiR-734-3p) and 2x (ssa-miR-2188-3p) lower in the SAV3-i4 infected group.

Table 1 DE miRNAs revealed by DESeq2 and RT-qPCR analysis in SAV3-i4 infected individuals at week 4 poc

\begin{tabular}{|c|c|c|c|c|c|c|}
\hline Mature miRNA & SAV expression ${ }^{1}$ & $\log 2$ fold change 2 & DESeq2 P-adj. ${ }^{3}$ & $\log 2$ f.c. RT-qPCR ${ }^{4}$ & RT-qPCR P-adj. ${ }^{5}$ & Family $^{6}$ \\
\hline ssa-miR-462a-5p & increase $13 x$ & 3.71 & $1.93 \times 10^{-5}$ & 2.58 & $3.0 \times 10^{-3}$ & 462 \\
\hline ssa-miR-462a-3p & increase 19x & 4.30 & $2.41 \times 10^{-5}$ & 3.12 & $3.0 \times 10^{-3}$ & 462 \\
\hline ssa-miR-462b-5p & increase $3 x$ & 1.75 & 0.07 & - & - & 462 \\
\hline ssa-miR-731-5p & increase $12 x$ & 3.58 & $1.79 \times 10^{-3}$ & 2.63 & $3.0 \times 10^{-3}$ & 731 \\
\hline ssa-miR-731-3p & increase $8 x$ & 3.04 & $1.64 \times 10^{-3}$ & 2.28 & $3.0 \times 10^{-3}$ & 731 \\
\hline ssa-miR-146b-5p & increase $14 x$ & 3.82 & $1.17 \times 10^{-4}$ & 2.38 & $3.0 \times 10^{-3}$ & 146 \\
\hline ssa-miR-146a-3p & increase $6 x$ & 2.64 & 0.03 & 2.99 & $3.0 \times 10^{-3}$ & 146 \\
\hline ssa-miR-146a-3-3p & increase $8 x$ & 3.00 & 0.03 & - & - & 146 \\
\hline ssa-miR-21a-1-3p & increase 10x & 3.27 & $4.3 \times 10^{-3}$ & 3.31 & $3.0 \times 10^{-3}$ & 21 \\
\hline ssa-miR-21a-2-3p & increase $8 x$ & 3.16 & 0.02 & 2.21 & $3.0 \times 10^{-3}$ & 21 \\
\hline ssa-miR-21b-3p & increase $5 x$ & 2.36 & 0.06 & 2.33 & $3.0 \times 10^{-3}$ & 21 \\
\hline ssa-miR-181c-5p & increase $4 x$ & 2.14 & 0.09 & 1.42 & 0.011 & 181 \\
\hline ssa-miR-223-5p & increase $5 x$ & 2.36 & 0.06 & 2.46 & $3.0 \times 10^{-3}$ & 223 \\
\hline ssa-miR-1338-3p & increase $3 x$ & 1.65 & 0.06 & 1.61 & $3.0 \times 10^{-3}$ & 1338 (1388) \\
\hline ssa-miR-155-5p & increase $3 x$ & 1.72 & 0.06 & 0.58 & 0.1 & 155 \\
\hline ssa-miR-92a-3-5p3 & increase 10x & 3.4 & 0.06 & - & - & 92 \\
\hline ssa-miR-7132-3p & increase $3 x$ & 1.79 & 0.06 & 1.88 & $3.0 \times 10^{-3}$ & 7132 \\
\hline ssa-miR-7132-5p & increase $4 x$ & 2.11 & 0.07 & 1.06 & 0.02 & 7132 \\
\hline ssa-miR-734-3p & decrease $4 x$ & -2.09 & 0.07 & -0.19 & 0.96 & 734 \\
\hline ssa-miR-2188-3p & decrease $2 x$ & -1.08 & 0.10 & -0.95 & $3.0 \times 10^{-3}$ & 2188 \\
\hline
\end{tabular}

${ }^{1}$ Direction and approximate relative change (times fold change) of mature miRNAs in SAV infected tisssues from DESeq2 measurements

${ }^{2}$ Log2 fold change from DESeq2 analysis of deep sequencing samples

${ }^{3}$ Adjusted $p$-values from DESeq2 analysis. 0.1 was used as threshold for significance

${ }^{4}$ Log2 fold change ( $\triangle \Delta C$ t-method) from RT-qPCR analysis

${ }^{5} P$-values from RT-qPCR after adjustment according to Benjamini-Hochberg procedure. 0.05 was used as threshold for significance

${ }^{6}$ Those with identical numbers belong to same miRNA gene family or are corresponding $5 p$ and $3 p$ from same miRNA gene 
The 20 DE miRNAs identified were derived from only 12 miRNA gene families (Table 1). MiRNAs that belong to the same gene family (e.g. ssa-miR-462a and ssa-miR$462 \mathrm{~b}$ ) are believed to be evolutionary very closely related and often co-expressed [34]. Thirteen DE miRNAs were from miRNA genes that are conserved through evolution and present also in higher vertebrates. Seven of the DE miRNAs were from four miRNA genes (miRNA7132, miRNA-734, miRNA-462 and miRNA-731) that have been discovered in teleosts only (http://www.mirbase.org/). Furthermore, two of these genes, miRNA-731 and miRNA-462a, are located within the same miRNA gene cluster in the Salmon genome [25].

\section{Validation of DESeq2 results by $R T$ - $q P C R$ analysis}

DESeq2 is a robust and widely used statistical tool for quantitative analysis of deep sequencing data. However, it is still common practice to validate any findings by use of an RT-qPCR method that can target each of the differentially expressed mature miRNAs individually. Such independent validations also allow for measurements of their expression in a larger population sample. Thus, for the purpose of validating our results we developed RT-qPCR assays to measure expression of the different DE miRNAs identified by DESeq2 analysis. Two miRNAs were not included in this validation (ssa-miR462b-5p and ssa-miR-146a-3-3p) as two other miRNAs (ssa-miR-462a-5p and ssa-miR-146a-3p) with very similar mature sequences from the same miRNA families were included. RT-qPCR assays were successfully developed for $17 \mathrm{DE}$ miRNAs. The miRNA specific primer sequences along with measurements of assay performances (R-squared and efficiency) for all these RT-qPCR assays are given in Additional file 2. One miRNA assay (ssa-miR-92a-3-5p) did not pass the validation of the RT-qPCR assay due to non-specific amplification and was not analysed further.
The comparative Ct method ( $\Delta \Delta$ Ct-method) [35] were used to measure the relative difference in miRNA levels between the healthy controls $(n=8)$ and SAV3-i4 positive individuals $(n=9)$ at week 4 poc. The results are summarized in Table 1. The log2 fold changes $(\Delta \Delta \mathrm{Ct})$ as well as adjusted p-values from each miRNA analysed by RT-qPCR is given. The results from RT-qPCR analysis agreed very well with the results from DESeq2 analysis for 15 of the 17 miRNAs tested. They all showed similar changes in expression which was significantly different compared to the controls (significant threshold $p=0.05$ ). The two remaining miRNAs (ssa-miR-155-5p and ssa-miR-734-3p) did reveal differences in the same direction as those from deep sequencing, but they were less pronounced and not significant. Considering the good agreement between DESeq2 analysis and RT-qPCR for the other 15 miRNAs it may be possible that the lack of correlation between the two methods for these two miRNAs was due to suboptimal RTqPCR assay performance. An efficiency in the lower range for these two RT-qPCR assays (Additional file 2) support that the RT-qPCR was the method providing the less accurate measurements of fold changes for these two miRNAs.

Figure 2 shows the results (log2 fold changes) for the 17 miRNAs that were analysed by both deep sequencing (DESeq2) and RT-qPCR ( $\Delta \Delta \mathrm{Ct}$-method). The figure illustrates the good agreement between the relative expression changes detected by the two methods. Spearman's nonparametric test for correlation showed $\rho=0.83(p=0.001)$. The good correlation between the methods also demonstrates that the RT-qPCR assays were suitable for measurements of miRNA expression in all SAV positive samples collected (three SAV groups, different time points).

\section{RT-qPCR analysis of miRNA expression in SAV2-i1, SAV3-i4 and SAV3-i6 groups}

The individuals in the three groups challenged with either SAV2-i1, SAV3-i4 or SAV3-i6 were successfully

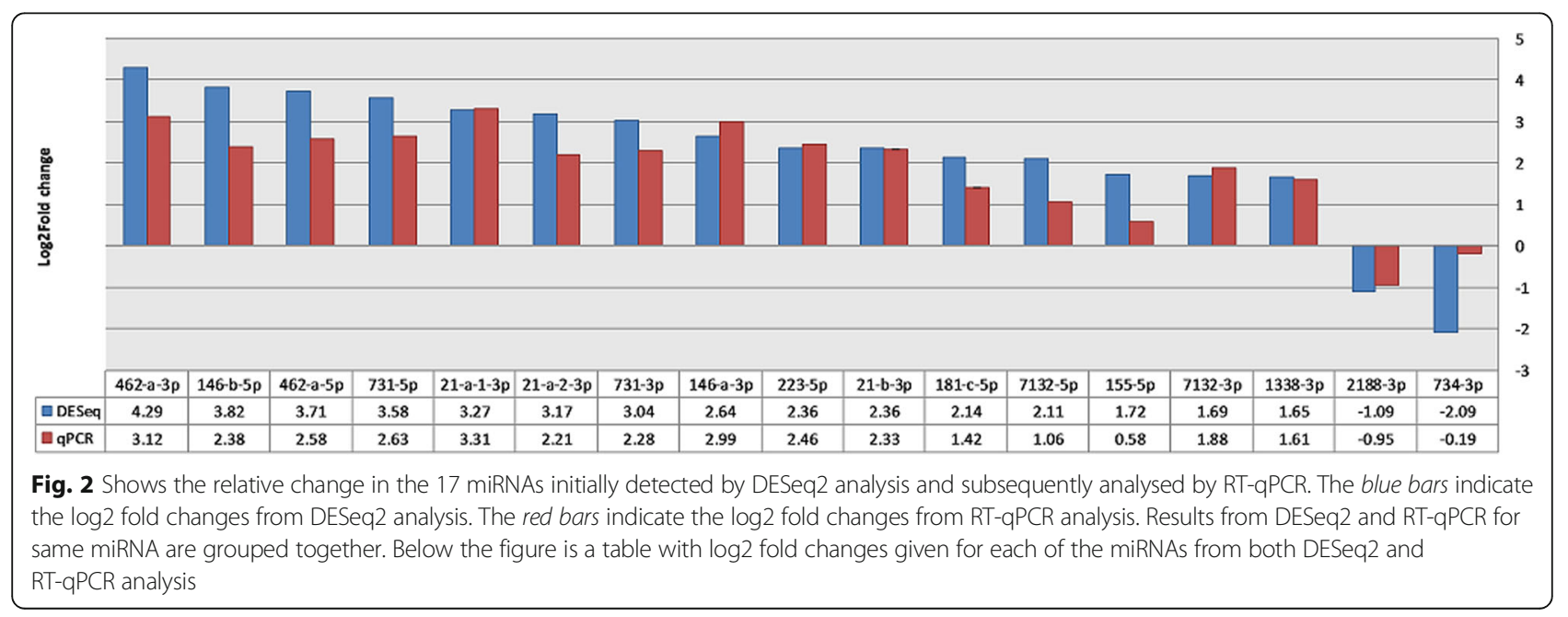


analysed by RT-qPCR at the three time points (week 2, 3 and 4 poc). The relative changes in expression $(\Delta \Delta C t)$ in the $17 \mathrm{DE}$ miRNAs were estimated by comparison to the control group. A complete overview of all results from RT-qPCR analysis showing the magnitude of change in each SAV-group at each of the time points along with measurements of significance (adjusted $p$-values) is given in Additional file 3.
The results from all time points showed that there was only one miRNA (ssa-miR-734-3p) that could not be verified by RT-qPCR as significantly different from the controls in any of the SAV groups. A majority of the miRNAs showed increased expression across the time points with the largest increases between week 3 and 4 poc, and the higher level of expression at the latest time point (week 4 poc) (Fig. 3). Viral load, on the other hand, showed the largest
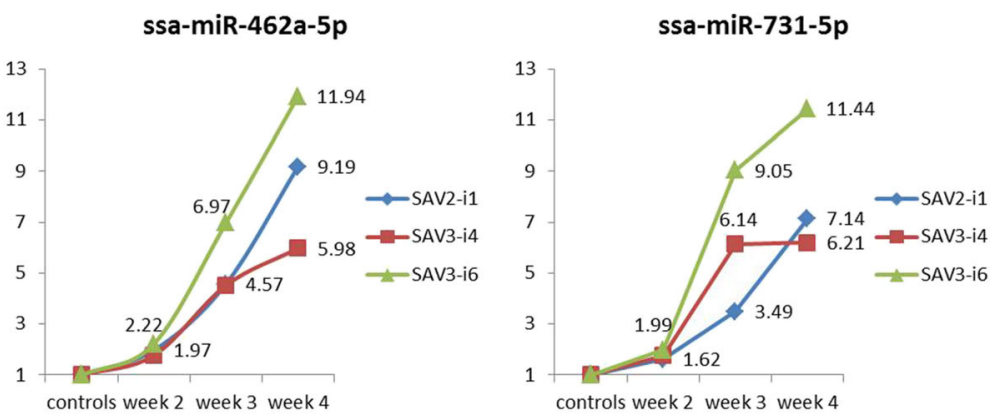

ssa-miR-146a-3p

ssa-miR-146b-5p
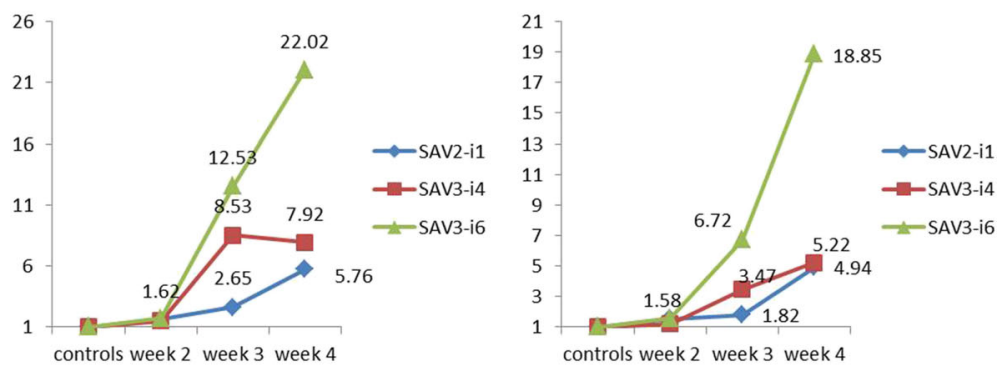

ssa-miR-223-5p

ssa-miR-181c-5p
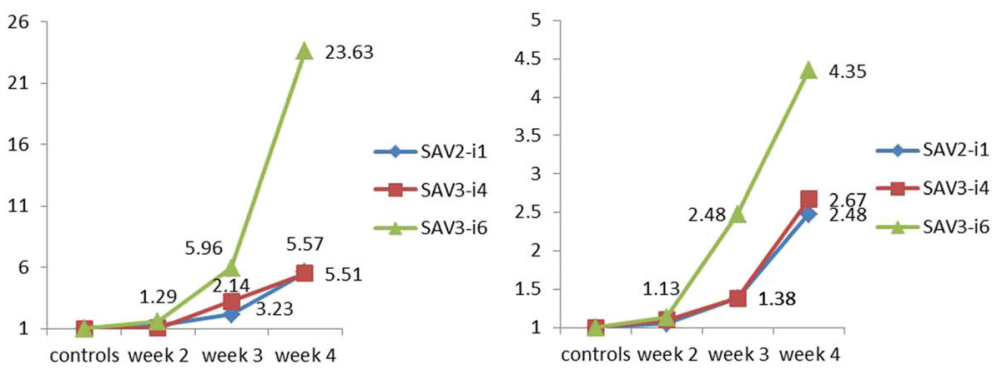

ssa-miR-155-5p

ssa-miR-7132-3p
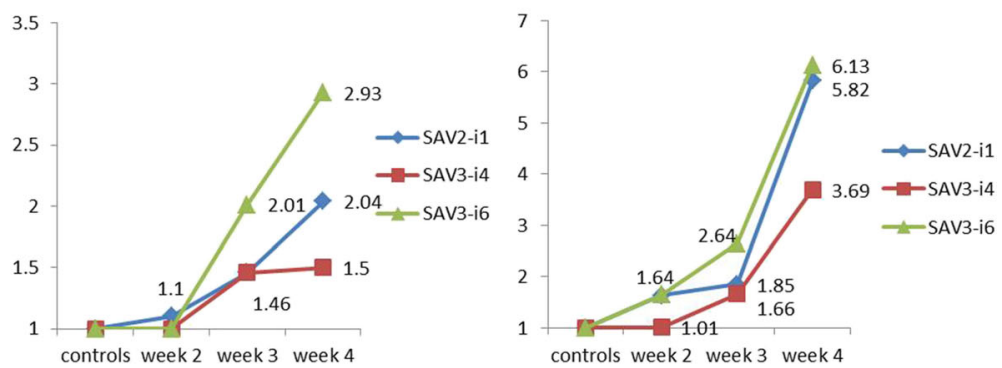

Fig. 3 Shows the relative changes in miRNA expression at all time points for each of the SAV groups for the following miRNAs: ssa-miR-462a-5p, ssa-miR-731-5p, ssa-miR-146a-3p, ssa-miR-146b-5p, ssa-miR-223-5p, ssa-miR-181c-5p, ssa-miR-155-5p and ssa-miR-7132-3p. The corresponding mature miRNAs from the miRNA gene cluster miRNA-462/731 (ssa-miR-462a-3p and ssa-miR-731-3p) showed very similar results, and for simplicity reasons these are not given in the figure, but in Additional file 3 
increases from week 2 to week 3 poc and modest changes from week 3 to week 4 poc (Fig. 1). Comparing the changes in miRNA expression with the changes in viral load, the expression of most of the miRNAs seem to mirror the change in viral load as if the large increases to the highest expression level at week 4 poc were a time delayed response to the large increase in viral load from week 2 to week 3 poc.

There were, however, differences in magnitude of the increases between groups. There were also differences in the direction of change between different miRNAs as some of the miRNAs revealed other changes than increases only (e.g. the miRNA-21 family and ssa-miR-1338-3p) (Fig. 4). These differences between groups are interesting as fish infected with either SAV2-i1, SAV3-i4 or SAV3-i6 have revealed differences in mortality rates [32].

\section{miRNAs with higher expression level in the SAV3-i6 group than the SAV3-i4/SAV2-i1 groups}

Ten of the 16 DE miRNAs (ssa-miR462a-5p and 3p, ssamiR-731-5p and 3p, ssa-miR-146a-3p, ssa-miR-146b-5p,
ssa-miR-223-5p, ssa-miR-181c-5p, ssa-miR-155-5p and ssa-7132-3p) showed increases across week 2, 3 and 4 poc in all SAV groups. Figure 3 illustrates the increases for eight of these miRNAs. The $5 p$ and $3 p$ mature miRNAs of ssa-miRNA-462a and ssa-miRNA-731-5p genes showed very similar patterns (see Additional file 3) and only the $5 p$ mature miRNAs were included in Fig. 3

The expressions were significantly different from the controls at week 3 and 4 poc in all three SAV groups in seven miRNAs; ssa-miR462a-5p, ssa-miR462a-3p, ssamiR-731-5p, ssa-miR-731-3p, ssa-miR-146a-3p ssa-miR223-5p and ssa-7132-3p. The miRNAs ssa-miR-155-5p, ssa-miR-181c-5p and ssa-miR-7132-3p were the miRNAs with the smallest increases in expression, and they were significantly different to controls in all groups at week 4 poc.

Common to all these ten miRNAs was that the SAV3i6 group revealed a higher expression than the SAV3-i4 and SAV2-i1 groups at week 3 and 4 poc. A comparison showed that in the four miRNAs ssa-miR-731-5p, ssa-

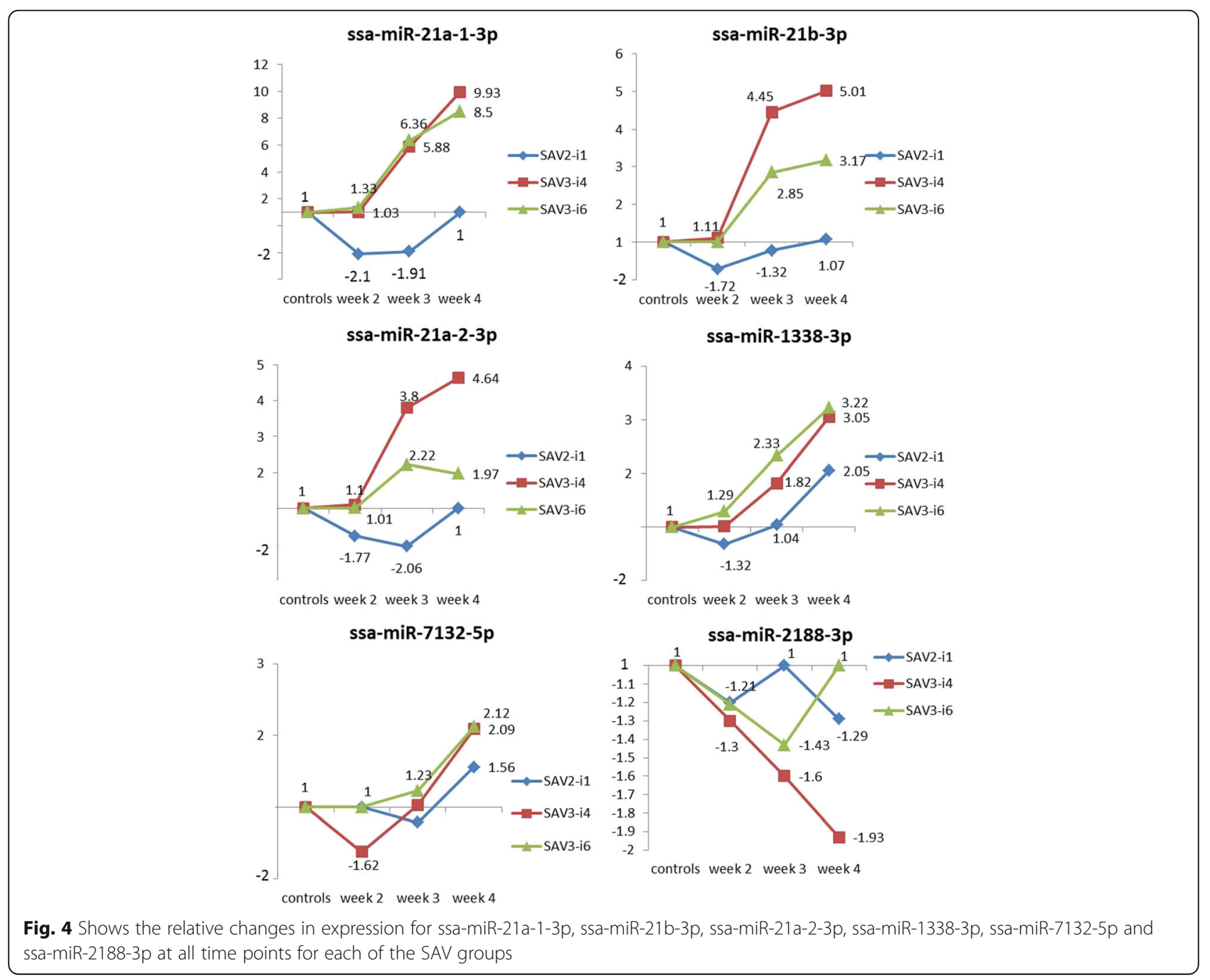


miR-146a-3p, ssa-miR-146b-5p and ssa-miR223-5p, there was a significant difference in expression in the SAV3-i6 group versus both the SAV2-i1 and SAV3-i4 groups at week 4 poc. Four of the other miRNAs ssamiR-462a-5p, ssa-miR-731-3p, ssa-miR-155-5p and ssa$7132-3 p$ showed significantly higher expression in the SAV3-i6 group than in the other SAV3 group (SAV3-i4) at week 4 poc. The SAV3-i4 and SAV2-i1 groups showed, in general, a more similar expression to each other than to the SAV3-i6 group (Fig. 3).

\section{miRNAs with decreased expression at early time points}

The miRNAs from the miRNA 21 family (ssa-miR-21a$1-3 p$, ssa-miR-21b-3p and ssa-miR-21a-2-3p) and miR1338-3p revealed a decreased expression across the early time points in the SAV2-i1 group. This was in contrast to the two other groups that showed unchanged or increased expression compared to controls at week 2 and 3 poc (Fig. 4). Interestingly, the SAV3-i4 group with the highest mortality rate also showed a higher expression of the three miRNAs from the miRNA 21 family than the SAV3-i6 group.

The changes in expression in ssa-miR-1338-3p were small in all SAV groups, but only the SAV2-i1 group showed a reduced expression, and the SAV2-i1 group was significantly different from SAV2-i6 at week 3 poc (Fig. 4). Ssa-miR-7132-5p and ssa-miR-2188-3p did both show a decreased expression at one or more time point in the SAV3-i4 group (Fig. 4). Ssa-miR-7132-5p showed a significant decrease at week 2 poc while ssa-miR-2188 revealed a decrease in expression across all time points in the SAV3-i4 group that was significantly different from both the controls and the SAV3-i6 group at week 4. Ssa-miR-734-3p showed a small decrease that was not significantly different to controls in any of the SAV groups (Additional file 3). However, this miRNA may have been more accurately measured in the DESeq 2 analysis (4x times decrease, Table 1 ).

\section{Prediction of miRNA target genes}

The four miRNA target prediction tools RNAhybrid, TargetSpy, PITA and Miranda [36, 37] were applied to predict the target genes. Two different approaches were used for selecting the genes used as input. First, we used a knowledge based approach where immune responsive genes known to respond to SAV infection [38, 39] were used as input. A few immune relevant genes known to be targets of the identified DE miRNAs in other vertebrates [40-45] were also included. Thus, a total of 50 genes (Additional file 4) were analysed in this first approach. Then we performed a second target gene prediction without any prior selection based on function or response to SAV. Applying such a holistic approach all known Atlantic salmon transcripts in the Refseq database of Genbank were considered putative targets and used as input. The latter approach would predict a large number of false positives [46], but could also potentially identify immune response related genes not previously identified as differentially expressed following SAV infection that are true targets.

The results from analyzing genes known to respond to SAV infection showed that 24 of the genes were predicted as putative targets by at least three of the prediction tools applied. The genes along with the mature miRNAs predicted to target each of these genes are shown in Table 2. Thirteen of the predicted target genes revealed multiple target sites to several different DE miRNAs in their 3'UTR's. Three of these genes, neutrophil cytosolic factor 1, myeloperoxidase and IKKa, were predicted to have target sites to five of the DE miRNAs. One of the miRNAs (miR-223-5p) predicted to target IKKa has also been reported as targeting this gene in other vertebrates [43].

On the other hand, 17 of the 20 DE miRNAs (Table 1) could target at least one gene. Additional file 5 illustrate such a duplex between a miRNA and the 3'UTR of the target gene. This particular match is between ssa-miR21b-3p and the 3'UTR of the Atlantic salmon IRF3 transcript. The distribution of miRNAs that were predicted to target multiple genes showed that 13 of the miRNAs; ssa-miR-462a-3p, ssa-miR-731-5p, ssa-miR-146b-5p, ssamiR-146a-3p, ssa-miR-146a-3-3p, ssa-miR-181c-5p, ssamiR-223-5p, ssa-miR-734-3p, ssa-miR-21a-2-3p, ssa-miR21b-3p, ssa-miR-1338-3p, ssa-miR-155-5p and ssa-miR2188-3p were predicted to target several genes. The miRNAs predicted to target the largest number of genes were the two miRNAs ssa-miR-223-5p and ssa-miR-181c-5p. These miRNAs showed target matches to nine and eight of the genes, respectively (Table 2). The miRNA showing largest number of target gene matches (miRNA-223) has been suggested as a diagnostic marker for inflammation in vertebrates [43]. Two of the mature miRNAs, ssa-miR462a-3p and miR-731-5p, that originate from the same miRNA gene cluster [25], were both predicted to target the 3'UTR of the same gene (macrosialin, Table 2). Two miRNAs showed down regulation at the later time points; ssa-miR-2188-3p and ssa-miR-734-3p (Fig. 2). Ssa-miR2188-3p showed a match to FOXO1 (cell death promotor) while ssa-miR-734-3p showed matches to interferon gamma (virus responsive cytokine), inhibitor of nuclear factor kappa-B kinase (IKKa) and viperine.

The conserved miRNAs miR-146, miR-155 and miR223 have been predicted to target important immune system response genes in other vertebrates (e.g. IRAK1, TRAF6, SOCS1 and STAT3) [40-43, 45]. The same Atlantic salmon miRNAs (ssa-miR-146, ssa-miR-155 and ssamiR-223) did not reveal any target site matches to the Atlantic salmon orthologs of these genes (Additional file 4). 
Table 2 Results from prediction of target genes among a set of SAV responsive immune network genes

\begin{tabular}{|c|c|c|c|c|}
\hline Gene & $\begin{array}{l}\text { Gene function/relevance to SAV } \\
\text { infection' }\end{array}$ & $\begin{array}{l}\text { Predicted by four search } \\
\text { tools }^{2}\end{array}$ & $\begin{array}{l}\text { Predicted by three search } \\
\text { tools }^{3}\end{array}$ & Reference $^{4}$ \\
\hline Neutrophil cytosolic factor 1 & $\begin{array}{l}\text { inflammatory response, superoxide anion } \\
\text { and cell death, increased expression in SAV }\end{array}$ & miR-92a-3-5p, miR-181c-5p & $\begin{array}{l}\text { miR-146a-3-3p, miR- } \\
\text { 146a-3p, miR-155-5p }\end{array}$ & Johansen et al., [38] \\
\hline $\begin{array}{l}\text { VHSV inducible like protein } \\
\text { (VIG-B319) }\end{array}$ & $\begin{array}{l}\text { virus responsive, increased expression in } \\
\text { VHSV and SAV }\end{array}$ & miR-155-5p, miR-223-5p & miR-146b-5p, miR-1338-3p & Johansen et al., [38] \\
\hline Jeltraxin & $\begin{array}{l}\text { similar to CRP, innate immunity pathway, } \\
\text { increased expression in SAV }\end{array}$ & miR-146b-5p & miR-181c-5p & Johansen et al., [38] \\
\hline $\begin{array}{l}\text { Interferon-inducible protein } \\
\text { Gig2-7-like }\end{array}$ & $\begin{array}{l}\text { virus responsive, increased expression } \\
\text { in SAV }\end{array}$ & - & miR-462a-3p & Johansen et al., [38] \\
\hline $\begin{array}{l}\text { Nuclear factor of kappa light } \\
\text { polypept gene enhancer in } \\
\text { B-cells } 2 \text { (NFkB2) }\end{array}$ & $\begin{array}{l}\text { miR-223 target in other vertebrate, innate } \\
\text { immune system, inflammatory response }\end{array}$ & miR-462a-3p & miR-146b-5p & Aziz et al., [43] \\
\hline Myeloperoxidase & $\begin{array}{l}\text { promote inflammation, innate immunity } \\
\text { pathway, increased expression in SAV }\end{array}$ & miR-462a-3p, miR-146b-5p & $\begin{array}{l}\text { miR-223-5p, miR-734-3p, } \\
\text { miR-2188-3p }\end{array}$ & Johansen et al., [38] \\
\hline Macrosialin precursor CD68 & $\begin{array}{l}\text { virus responsive, increased expression } \\
\text { in SAV }\end{array}$ & miR-462a-3p, miR-731-5p & miR-181c-5p & Johansen et al., [38] \\
\hline $\begin{array}{l}\text { ATP-dependent RNA helicase } \\
\text { DHX58 (RIG-I-like 3) }\end{array}$ & $\begin{array}{l}\text { virus responsive, innate immunity pathway, } \\
\text { increased expression in SAV }\end{array}$ & - & miR-731-5p & Johansen et al., [38] \\
\hline $\begin{array}{l}\text { Interferon regulatory factor } \\
7 \text { (IRF7) }\end{array}$ & $\begin{array}{l}\text { transcription factor activating innate } \\
\text { immunity pathway, increased expression } \\
\text { in SAV }\end{array}$ & miR-731-5p & - & Xu et al., [39] \\
\hline $\begin{array}{l}\text { Interferon regulatory factor } \\
3 \text { (IRF3) }\end{array}$ & $\begin{array}{l}\text { transcription factor activating innate } \\
\text { immunity pathway, increased expression } \\
\text { in SAV }\end{array}$ & miR-21a-2-3p, miR-21b-3p & miR-181c-5p, miR-734-3p & Xu et al., [39] \\
\hline $\mathrm{C}-\mathrm{C}$ motif chemokine 19 & $\begin{array}{l}\text { inflammatory response, innate immunity } \\
\text { pathway, increased expression in SAV }\end{array}$ & - & $\begin{array}{l}\text { miR-731-3p, miR-223-5p, } \\
\text { miR-1338-3p }\end{array}$ & Johansen et al., [38] \\
\hline $\begin{array}{l}\text { Interferon-inducible protein } \\
\text { Gig2-2-like }\end{array}$ & $\begin{array}{l}\text { virus responsive, increased expression } \\
\text { in SAV }\end{array}$ & miR-181c-5p & - & Johansen et al., [38] \\
\hline $\begin{array}{l}\text { Inhibitor of nuclear factor kappa- } \\
\text { B kinase subunit alpha-like (IKKa) }\end{array}$ & $\begin{array}{l}\text { miR-223 target in other vertebrate, innate } \\
\text { immune system and inflammatory response }\end{array}$ & miR-181c-5p (multiple sites) & $\begin{array}{l}\text { miR-223-5p, miR-7132-5p, } \\
\text { miR-1338-3p, miR-734-3p }\end{array}$ & Aziz et al., [43] \\
\hline $\begin{array}{l}\text { Cholesterol 25-hydroxylase-like } \\
\text { protein A }\end{array}$ & $\begin{array}{l}\text { virus responsive, innate immunity pathway, } \\
\text { increased expression in SAV }\end{array}$ & miR-181c-5p & - & Johansen et al., [38] \\
\hline Complement factor D (CFAD) & $\begin{array}{l}\text { inflammatory response, innate immunity } \\
\text { pathway, upregulated in SAV }\end{array}$ & - & miR-223-5p & Johansen et al., [38] \\
\hline $\begin{array}{l}\text { Interleukin-10 receptor beta } \\
\text { chain precursor }\end{array}$ & $\begin{array}{l}\text { Cytokine-mediated signaling pathway, } \\
\text { immune response, upregulated in SAV }\end{array}$ & - & $\begin{array}{l}\text { miR-21a-2-3p, miR-146a-3-3p, } \\
\text { miR-146a-3p, miR-223-5p }\end{array}$ & Johansen et al., [38] \\
\hline SOCS1 & antiviral innate immune response & - & miR-223-5p & Taganov et al., [45] \\
\hline Fish virus induced TRIM-3 & $\begin{array}{l}\text { Virus responsive, antiviral innate immunity, } \\
\text { upregulated in SAV }\end{array}$ & - & miR-181c-5p & Johansen et al., [38] \\
\hline $\begin{array}{l}\text { Forkhead box protein O1-A-like } \\
\text { (FOXO1) }\end{array}$ & $\begin{array}{l}\text { miR-223 target in other vertebrate, immune } \\
\text { system signaling pathways, promote cell } \\
\text { death }\end{array}$ & - & miR-2188-3p & Aziz et al., [43] \\
\hline $\begin{array}{l}\text { Complement } \mathrm{C} 1 \mathrm{qB} \\
\text { subcomponent }\end{array}$ & $\begin{array}{l}\text { inflammatory response, innate immunity } \\
\text { pathway, increased expression in SAV }\end{array}$ & - & $\begin{array}{l}\text { miR-21a-1-3p, miR-223-5p, } \\
\text { miR-2188-3p (multiple sites) }\end{array}$ & Johansen et al., [38] \\
\hline Barrier-to-autointegration factor & $\begin{array}{l}\text { known to be exploited by retrovirus, } \\
\text { increased expression in SAV }\end{array}$ & - & miR-21a-2-3p, miR-21b-3p & Johansen et al., [38] \\
\hline Viperine (RSAD2) & $\begin{array}{l}\text { virus responsive, innate immunity antiviral, } \\
\text { increased expression in SAV }\end{array}$ & - & miR-223-5p, miR-734-3p & Johansen et al., [38] \\
\hline Interferon gamma 1 & virus responsive, cytokine & - & miR-734-3p & Sun et al., [40] \\
\hline Interferon gamma 2 & virus responsive, cytokine & - & miR-734-3p & Sun et al., [40] \\
\hline
\end{tabular}

${ }^{1}$ Key words about gene function are based on gene function description in the http://www.uniprot.org/uniprot/ database. ${ }^{2} \mathrm{DE}-\mathrm{miRs}$ predicted to target the gene by all the four target search tools used (RNA-hybrid, TargetSpy, PITA, Miranda)

${ }^{3} \mathrm{DE}$-miRs predicted to target the gene by three of the four target search tools used. ${ }^{4}$ Relevance to $\mathrm{SAV}$ is based on findings in the references given in this column

On the other hand, the teleost specific miRNA, miR-731$5 \mathrm{p}$, has been shown to target IRF7 in Japanese flounder [44]. This gene (IRF7) was also predicted as a target gene in Atlantic salmon where ssa-miR-731-5p showed a target site match to the 3'UTR of the Atlantic salmon IRF7 transcript (Table 2). Likewise, the miR-223-5p has been 
predicted to target IKKa in humans [43] and did also reveal target site in the 3'UTR of the Atlantic salmon IKKa transcript. The conservation of these target sites among distant vertebrate species indicates that these two genes are true targets of ssa-miR-731-5p and ssa-miR-223-5p. In summary, the findings from target gene prediction in the set of SAV responsive genes indicated that 24 genes, many that are key participants in the immune system networks and known to respond to SAV infection, may be negatively regulated by the DE miRNAs identified in this study.

The target gene predictions applying all Atlantic salmon mRNAs (Refseq, Genbank) as input (holistic approach) generated matches to a total of 1335 transcripts. Each DE miRNA was predicted to target several transcripts with numbers ranging from 30 transcripts (miR-7132-3p) to 389 (miR-181c-5p). The complete results from this analysis, showing the predicted target transcripts along with the matching mature miRNAs are given in Additional file 6.

A subset of 28 genes predicted as targets applying the holistic approach were immune response network genes (Table 3) that was not discovered using the SAV responsive set of genes as input in the target gene predictions. Although an association between these genes and SAV has not been reported, the in silico prediction analysis indicates that these genes may also be among the genes targeted by the DE miRNAs. The majority of these transcripts encode proteins with roles as activators (IRF1, IRF4, IRF5) and effectors (chemokine receptors) in the immune responses while a few of them are inhibitors (e.g. NFKappaB inhibitor) (Table 3).

\section{Genome sequence analysis of DE miRNA genes to identify putative cis-elements}

The genome sequence of the miRNA precursors and their location within the Atlantic salmon genome was described in Andreassen et al. [25], and an updated version of the Atlantic salmon genome sequence was recently uploaded in Genbank (Genbank \# GCF_000233375.1). Together these sources were utilized to identify and analyze the upstream sequences of the DE miRNA genes. The 20 short mature DE miRNAs could be processed from 25 miRNA genes as some of the mature miRNAs could originate from highly similar duplicated miRNA genes. While the upstream genome sequence was not available for one of the genes (miRNA-155-2), the genome sequences from the other 24 miRNA genes could be included in the genome sequence analysis. They were all analyzed regarding presence of the consensus sequences of eight conserved promoter motifs known to bind immune-responseactivated transcription factors (Additional file 7). The presence of such elements could indicate that their transcription was enhanced by transcription factors that are part of the innate immune response gene network.
The results from the search for response elements in the immediate upstream sequences of the DE miRNA genes are summarized in Table 4. Ten of the genes revealed TATA-box motifs, a finding in agreement with Long et al. [47]. More interestingly, two or more of the eight promoter motifs were observed in the immediate upstream sequences of all genes except miRNA-734 and miRNA-2188 that did not reveal any of the motifs in their upstream sequences. The miRNA-462a/731 gene cluster as well as the single miRNA-462b gene revealed the "classical" ISRE motif (ISRE-IRF1 in Table 4), the PU.1 motif and the GAS motif which have also been identified in the upstream sequence of the miRNA-462a/ 731 gene cluster in rainbow trout [28]. In addition, there were three more out of the eight promoter motifs present upstream of this gene cluster (Table 4). The "classical" ISRE motif was also present in the miRNA146b and miRNA-155-1 genes along with three or more of the other motifs. In agreement with findings that miRNA-155 transcription is regulated through binding to NF-kappaB and ETS2 motifs [48], these motifs were also present in the Atlantic salmon miRNA-155-1 gene. In summary, the genome analysis showed that there was a high density of motifs known to bind transcription factors activated by the innate immune system in the upstream genome sequences of the DE miRNA genes. This indicates that transcription of many of the DE miRNA genes may be enhanced by some of the key transcription factors of the innate immune system. The two miRNA genes, miRNA-734 and miRNA-2188, that did not have any matches to the conserved motifs in their upstream sequences were the ones that revealed a decrease of their mature miRNAs following infection (Table 1).

\section{Discussion}

DE miRNAs may participate in negative feedback loops in the host innate immune system

The quantitative analysis of the results from the deep sequencing followed by RT-qPCR validations identified a subset of mature miRNAs that are differentially expressed following SAV infection in Atlantic salmon (DE miRNAs). The relative expression of the DE miRNAs was subsequently measured across three time points post onset of challenge in fish infected with either SAV2-i1, SAV3-i4 or SAV3-i6 (Figs. 3 and 4).

The DE miRNAs were predicted to target a number of key genes of the innate immune system. Some are among the important activators of the innate immune responses like the ATP-dependent RNA helicase DHX58 as well as the transcription factors IRF3 and IRF7. Other innate immune response network genes that were predicted as targets were interferon gamma (IFN- $\gamma$ ) and interferon stimulated genes like viperine (RSAD2), $\mathrm{C}-\mathrm{C}$ 
Table 3 Predicted target genes with immune response related function from in silico analysis using the Atlantic salmon transcriptome as input (holistic apporach)

\begin{tabular}{|c|c|c|c|c|}
\hline Gene & Gene function $^{1}$ & $\begin{array}{l}\text { Predicted by four } \\
\text { search tools }\end{array}$ & $\begin{array}{l}\text { Predicted by three } \\
\text { search tools }\end{array}$ & Reference $^{4}$ \\
\hline $\begin{array}{l}\text { Interferon regulatory factor } \\
\text { 2-binding protein 2-A }\end{array}$ & $\begin{array}{l}\text { Repressor, regulation of transcription, represses } \\
\text { the NFAT1-dependent transactivation of NFAT- } \\
\text { responsive promoters }\end{array}$ & miR-223_5p & - & NM_001139853.1 \\
\hline $\begin{array}{l}\text { interferon regulatory factor } \\
5 \text { (IRF5) }\end{array}$ & $\begin{array}{l}\text { Transcription factor activator that promote } \\
\text { inflammation, innate immune system, Antiviral } \\
\text { defense }\end{array}$ & miR-181c-5p & miR-462a-3p & NM_001139852.1 \\
\hline CD226 antigen precursor & $\begin{array}{l}\text { Activator, Receptor involved in cytokine production, } \\
\text { regulation of immune response in innate immune } \\
\text { system }\end{array}$ & miR-146a-3p, miR-181c-5p & miR-7132-3p & NM_001139914.1 \\
\hline $\begin{array}{l}\text { POU domain class } \\
\text { 2-associating factor } 1\end{array}$ & $\begin{array}{l}\text { Transcriptional coactivator, humoral immune } \\
\text { response }\end{array}$ & miR-181c-5p & - & NM_001140075.1 \\
\hline Suppressor of IKK-epsilon & $\begin{array}{l}\text { inhibitory role in virus- and TLR3-triggered IRF3, } \\
\text { Inhibits TLR3-mediated activation of interferon- } \\
\text { stim. response elements (ISRE) }\end{array}$ & miR-146a-3-3p, miR-146a-3p & $\begin{array}{l}\text { miR-21a-2-3p, } \\
\text { miR-21b-3p }\end{array}$ & NM_001140308.1 \\
\hline NF-kappa-B inhibitor epsilon & $\begin{array}{l}\text { Inhibition of NFkB, innate immune system } \\
\text { signaling pathway }\end{array}$ & miR-181c-5p & miR-146b-5p & NM_001140380.1 \\
\hline $\begin{array}{l}\text { Interferon-induced protein } \\
44 \text { (IFI44) }\end{array}$ & GTP binding, antiviral defense & miR-21b-3p & miR-21a-2-3p & NM_001140400.1 \\
\hline C-C chemokine receptor type 9 & $\begin{array}{l}\text { Transcription coactivator binding, chemokine } \\
\text { receptor activity, immune response }\end{array}$ & - & $\begin{array}{l}\operatorname{miR}-181 c-5 p \\
\operatorname{miR}-731-5 p\end{array}$ & NM_001140518.1 \\
\hline $\begin{array}{l}\text { C-C motif chemokine } 25 \\
\text { precursor }\end{array}$ & $\begin{array}{l}\text { Effector, chemokine-mediated signaling pathway, } \\
\text { immune response, inflammatory response }\end{array}$ & miR-155-5p & - & NM_001140865.1 \\
\hline $\begin{array}{l}\text { C-X-C motif chemokine } 10 \\
\text { precursor }\end{array}$ & $\begin{array}{l}\text { Chemokine-mediated signaling pathway, } \\
\text { effector, immune response, inflammatory } \\
\text { response }\end{array}$ & miR-181c-5p & :miR-21b-3p & NM_001141028.1 \\
\hline $\begin{array}{l}\text { Interleukin-20 receptor alpha } \\
\text { chain precursor }\end{array}$ & $\begin{array}{l}\text { Activator, cytokine-mediated signaling pathway, } \\
\text { Interleukin } 20 \text { binding, immune system }\end{array}$ & - & miR-92a-3-5p & NM_001141080.1 \\
\hline $\begin{array}{l}\text { C-C motif chemokine } 21 \\
\text { precursor }\end{array}$ & $\begin{array}{l}\text { Chemokine-mediated signaling pathway, } \\
\text { effector, immune response, inflammatory } \\
\text { response }\end{array}$ & miR-92a-3-5p & $\begin{array}{l}\text { miR-21a-2-3p, } \\
\text { miR-21b-3p }\end{array}$ & NM_001141267.2 \\
\hline $\begin{array}{l}\text { interferon-induced, ds RNA- } \\
\text { activated protein kinase }\end{array}$ & $\begin{array}{l}\text { Activator and effector, Antiviral defense, Host- } \\
\text { virus interaction, Immunity, Innate immunity, } \\
\text { Transcription, Transcription regulation }\end{array}$ & miR-146b-5p & - & NM_001141332.2 \\
\hline C-C chemokine receptor type 3 & $\begin{array}{l}\text { Effector, chemokine receptor activity, } \\
\text { inflammatory response, Host-virus interaction, } \\
\text { cellular defense response }\end{array}$ & - & miR-7132-3p & NM_001173762.1 \\
\hline $\begin{array}{l}\text { Interleukin-31 receptor A } \\
\text { precursor }\end{array}$ & $\begin{array}{l}\text { Transcription coactivator, activates STAT3, } \\
\text { cytokine receptor activity, acute inflammatory } \\
\text { response to antigenic stimulus }\end{array}$ & - & miR-1338-3p & NM_001173970.1 \\
\hline $\begin{array}{l}\text { interferon regulatory factor } 1 \\
\text { (IRF1) isoform } 2\end{array}$ & $\begin{array}{l}\text { Activator, promote antiviral innate immunity } \\
\text { response, Transcription regulation }\end{array}$ & miR-462b-5p & miR-7132-5p & NM_001252364.1 \\
\hline $\begin{array}{l}\text { interleukin } 1 \text { receptor } \\
\text { accessory protein precursor }\end{array}$ & $\begin{array}{l}\text { Activator, IL-1 signaling pathway, Immunity, } \\
\text { Inflammatory response, innate immune response }\end{array}$ & miR-2188-3p & - & NM_001123552.1 \\
\hline $\begin{array}{l}\text { CCL4-like chemokine } \\
\text { precursor }\end{array}$ & $\begin{array}{l}\text { Effector, chemokine-mediated signaling pathway, } \\
\text { immune response, inflammatory response }\end{array}$ & miR-146a-3-3p, miR-146a-3p & - & NM_001123618.1 \\
\hline C-C chemokine receptor type 6 & $\begin{array}{l}\mathrm{C}-\mathrm{C} \text { chemokine binding, cellular defense } \\
\text { response, innate immune response }\end{array}$ & miR-181c-5p & - & NM_001139972.1 \\
\hline $\begin{array}{l}\text { Interferon regulatory factor } \\
4 \text { (IRF4) }\end{array}$ & $\begin{array}{l}\text { Transcriptional activator, type I interferon } \\
\text { signaling pathway, binds to ISRE, immune } \\
\text { system pathways }\end{array}$ & - & miR-731-5p & NM_001139982.1 \\
\hline $\begin{array}{l}\text { Interleukin-13 receptor alpha-2 } \\
\text { chain precursor }\end{array}$ & $\begin{array}{l}\text { Cytokine receptor activity, immunoglobulin } \\
\text { mediated immune response, negative } \\
\text { regulation of immunoglobulin production }\end{array}$ & miR-731-3p & miR-731-5p & NM_001140169.1 \\
\hline
\end{tabular}


Table 3 Predicted target genes with immune response related function from in silico analysis using the Atlantic salmon transcriptome as input (holistic apporach) (Continued)

\begin{tabular}{|c|c|c|c|c|}
\hline $\begin{array}{l}\mathrm{C}-\mathrm{X}-\mathrm{C} \text { chemokine receptor } \\
\text { type } 3\end{array}$ & $\begin{array}{l}\text { Receptor for C-X-R chemokines, regulates } \\
\text { biological processes such as inflammation, } \\
\text { immunity, and would healing }\end{array}$ & miR-731-5p & miR-734-3p & NM_001140493.1 \\
\hline $\begin{array}{l}\text { nuclear factor NF-kappa-B } \\
\text { p100 subunit }\end{array}$ & $\begin{array}{l}\text { Activator and repressor, transcr. factor activity, } \\
\text { NF-kappaB signaling pathway, innate immune } \\
\text { response, innflammatory response }\end{array}$ & - & miR-462a-3p & NM_001173583.1 \\
\hline $\begin{array}{l}\text { toll-like leucine-rich repeat } \\
\text { precursor }\end{array}$ & $\begin{array}{l}\text { Activator, Immunity, Inflammatory response, } \\
\text { Innate immunity }\end{array}$ & miR-731-5p & miR-2188-3p & NM_001123691.1 \\
\hline $\begin{array}{l}\text { Macrophage migration } \\
\text { inhibitory factor (MIF) }\end{array}$ & $\begin{array}{l}\text { Inhibitor/surpressor, Inflammatory response, } \\
\text { innate immune response, cell-mediated immunity }\end{array}$ & miR-155-5p & - & NM_001141547.1 \\
\hline $\begin{array}{l}\text { BCL2/adenovirus E1B } \\
\text { interacting protein 3-like }\end{array}$ & $\begin{array}{l}\text { Effector, negative regulation of apoptotic } \\
\text { process, Host-virus interaction, defense } \\
\text { response to virus }\end{array}$ & $\begin{array}{l}\text { miR-1338-3p, miR-146b-5p, } \\
\text { miR-181c-5p, miR-731-5p }\end{array}$ & - & NM_001141679.1 \\
\hline TRAF2-binding protein & $\begin{array}{l}\text { mediates the IRAK1 and TRAF6 interaction } \\
\text { following IL-1 stimulation, I-kappaB kinase/ } \\
\text { NF-kappaB signaling }\end{array}$ & - & miR-462a-3p & NM_001173784.1 \\
\hline $\begin{array}{l}\text { single Ig IL-1-related receptor } \\
\text { precursor }\end{array}$ & $\begin{array}{l}\text { Acute-phase response, neg. reg. of cytokine- } \\
\text { mediated signaling pathway, neg. reg.of } \\
\text { sequence-specific DNA binding transcription } \\
\text { factor activity }\end{array}$ & miR-181c-5p, miR-462a-3p & - & NM_001173838.1 \\
\hline
\end{tabular}

${ }^{1}$ Key words about gene function are based on gene function description in the http://www.uniprot.org/uniprot/ database. ${ }^{2} \mathrm{DE}-\mathrm{miRs}$ predicted to target the gene by all the four target search tools used (RNA-hybrid, TargetSpy, PITA, Miranda)

${ }^{3} \mathrm{DE}-\mathrm{miRs}$ predicted to target the gene by three of the four target search tools used. ${ }^{4}$ Genbank reference number

motif chemokine 19, interferon-inducible protein Gig22-like, Gig2-7-like and myeloperoxidase (Table 2). These genes are all known to respond to SAV infection [38, 39]. Extending the search for putative target genes to the Atlantic salmon transcriptome identified 28 additional immune network genes as putative targets (Table 3). The majority of the putative target genes act as activators or effector molecules in the innate immune system pathway. If they are true target genes they are negatively regulated by DE miRNAs.

The role of the DE miRNAs in the host-virus interaction would not only depend on what target genes they regulate, but would also depend on what time post viral infection their expression changes as well as the direction of change. Several recent reviews [11, 49-51] suggest that some miRNAs targeting activator and effector transcripts could have a role in promoting early immune response if their expression was decreased at the early stage of an immune response. In the late phase of inflammation, some miRNAs that target activator and effector transcripts have been suggested to have another role. In this phase increased expression of these miRNAs may help prevent pathological inflammatory processes. In this role the miRNAs stabilize and prevent further increase of activator and effector transcripts, and both the targets and miRNAs would have increased expression compared to the normal cellular state. The expression of some miRNAs believed to negatively regulate the immune response in the late phase of infection seem to be induced by immune network transcription factors. In such cases the miRNAs participate in negative feedback loops as their expression is enhanced by their targets $[11,49]$.

The viral loads increased across the three first time points (week 1, 2 and 3 poc) in all the SAV groups, but seemed to decline at week 4 poc in SAV3-i6. The viral loads in the two other groups also seemed to have reached their maximum level at week 4 poc as the increases were much less pronounced from week 3 to week 4 poc (Fig. 1). These observations are in agreement with findings in Taksdal et al. [32] where the viral loads declined in all SAV groups after week 4 poc. Ten of the miRNAs (e.g. the eight miRNAs in Fig. 3) showed minor increases across the first time point (week 2 poc), but larger increases towards the last time point (week 4 poc). The findings from measurements of viral load showed that all fish had been infected for more than a week at the last time point (week 4 poc, Fig. 1). Comparing the increases in viral loads with the change in miRNA expression the latter appear as a time delayed response to viral infection. This could indicate that the purpose of the increases, resulting in a high expression of the DE miRNAs more than a week post maximum measurements of viral loads, were to negatively regulate the expression of inflammatory mediators to prevent excess inflammation $[50,51]$. Many DE miRNAs showed a time delayed increase of the DE miRNAs (Fig. 3) and they were predicted to target immune response activators. This could suggest that their role were to prevent a prolonged or elevated immune response that would be harmful to the host $[11,49]$. 
Table 4 Transcription factor binding motifs in the upstream genome sequences of DE miRNA genes

\begin{tabular}{|c|c|c|c|c|c|c|c|c|c|c|}
\hline miRNA gene & $\begin{array}{l}\text { upstream } \\
\text { TATA-box }\end{array}$ & $\begin{array}{l}\text { ISRE-IRF1 } \\
\text { M00972 }\end{array}$ & $\begin{array}{l}\text { IRF1 } \\
\text { M00747 }\end{array}$ & PU.1 & GAS & $\begin{array}{l}\text { IRF3 } \\
\text { M00772 }\end{array}$ & $\begin{array}{l}\text { IRF8 } \\
\text { M01665 }\end{array}$ & $\begin{array}{l}\text { NF-kappaB } \\
\text { M00051 }\end{array}$ & $\begin{array}{l}\text { ETS2 } \\
\text { M00340 }\end{array}$ & Genbank Accesion \# \\
\hline miR462a/731 cluster & 1 & 2 & 1 & 1 & 2 & 1 & 1 & - & - & $\begin{array}{l}\text { gi|925216714:63629639- } \\
63631038 \text { (NC_027314.1) }\end{array}$ \\
\hline ssa-mir-462b & 1 & 2 & 1 & 1 & 1 & 2 & 1 & - & - & $\begin{array}{l}\text { gi|925216718:28307432- } \\
28308831 \text { (NC_027312.1) }\end{array}$ \\
\hline ssa-mir-146a-1 & - & - & - & - & 3 & - & 1 & - & - & $\begin{array}{l}\text { gi|925216706:4556929- } \\
4558189 \text { (NC_027317.1) }\end{array}$ \\
\hline ssa-mir-146a-2 & - & - & - & - & 2 & - & - & - & - & $\begin{array}{l}\text { gi|925216783:47301787- } \\
47303047 \text { (NC_027300.1) }\end{array}$ \\
\hline ssa-mir-146b & - & 1 & 1 & - & 5 & - & 1 & - & - & $\begin{array}{l}\text { gi|925216704:2641623- } \\
2642883 \text { (NC_027318.1) }\end{array}$ \\
\hline ssa-mir-146a-3 & - & - & 3 & - & 3 & - & - & - & - & $\begin{array}{l}\text { gi|925216704:51691919- } \\
51693179 \text { (NC_027318.1) }\end{array}$ \\
\hline ssa-mir-21a-1 & 2 & - & - & - & 1 & - & 1 & - & - & $\begin{array}{l}\text { gi|925216727:116610294- } \\
116611574 \text { (NC_027308.1) }\end{array}$ \\
\hline ssa-mir-21a-2 & 1 & - & - & - & 1 & - & 2 & - & - & $\begin{array}{l}\text { gi|925216702:60966622- } \\
60967902 \text { (NC_027319.1) }\end{array}$ \\
\hline ssa-mir-21b-1 & 1 & - & - & - & 1 & - & 1 & - & - & $\begin{array}{l}\text { gi|925216769:50774080- } \\
50775360 \text { (NC_027303.1) }\end{array}$ \\
\hline ssa-mir-21b-2 & - & - & 1 & - & 1 & 1 & 1 & - & - & $\begin{array}{l}\text { gi|925216718:73813159- } \\
73814439 \text { (NC_027312.1) }\end{array}$ \\
\hline ssa-mir-1338 & - & - & 2 & - & 1 & - & 2 & - & - & $\begin{array}{l}\text { gi|925216772:45802741- } \\
45804012 \text { (NC_027302.1) }\end{array}$ \\
\hline ssa-mir-155-1 & - & 1 & - & - & 6 & - & - & 1 & 1 & $\begin{array}{l}\text { gi|925146043:6698-7958 } \\
\text { (NW_012350889.1) }\end{array}$ \\
\hline ssa-mir-92a-3 & - & - & - & - & 1 & - & - & - & - & $\begin{array}{l}\text { gi|925125935:50220-51479 } \\
\text { (NW_012343521.1) }\end{array}$ \\
\hline ssa-mir-7132b-1 & 2 & - & - & 1 & 4 & - & - & - & - & $\begin{array}{l}\text { gi|925216780:448666633- } \\
44867894 \text { (NC_027301.1) }\end{array}$ \\
\hline ssa-mir-7132b-2 & 3 & - & - & 1 & 1 & - & - & - & - & $\begin{array}{l}\text { gi|925216720:24179665- } \\
24180926 \text { (NC_027311.1) }\end{array}$ \\
\hline ssa-mir-7132a-1 & - & - & 1 & 1 & 1 & - & 1 & - & - & $\begin{array}{l}\text { gi|925216772:70457167- } \\
70458424 \text { (NC_027302.1) }\end{array}$ \\
\hline ssa-mir-7132a-2 & - & - & 1 & 1 & 1 & - & - & - & - & $\begin{array}{l}\text { gi|925216757:28942285- } \\
28943542 \text { (NC_027305.1) }\end{array}$ \\
\hline ssa-mir-734 & - & - & - & - & - & - & - & - & - & $\begin{array}{l}\text { gi|925216691:29709642- } \\
29710902 \text { (NC_027324.1) }\end{array}$ \\
\hline ssa-mir-181b & 1 & - & - & - & - & 1 & - & - & - & $\begin{array}{l}\text { gi|925216772:43728947- } \\
43730207 \text { (NC_027302.1) }\end{array}$ \\
\hline ssa-mir-181c & 1 & - & - & - & 2 & - & - & - & - & $\begin{array}{l}\text { gi|925216723:49524703- } \\
49525962 \text { (NC_027310.1) }\end{array}$ \\
\hline ssa-mir-2188-1 & - & - & - & - & - & - & - & - & - & $\begin{array}{l}\text { gi|925216702:26812353- } \\
26813612 \text { (NC_027319.1) }\end{array}$ \\
\hline ssa-mir-2188-2 & - & - & - & - & - & - & - & - & - & $\begin{array}{l}\text { gi|925216694:16936155- } \\
16937414 \text { (NC_027323.1) }\end{array}$ \\
\hline miR-223-1 & 1 & - & 1 & - & 4 & - & 1 & - & - & $\begin{array}{l}\text { gi|925216769:43698893- } \\
43700211 \text { (NC_027303) }\end{array}$ \\
\hline miR-223-2 & - & - & 1 & - & 2 & 1 & 1 & - & - & $\begin{array}{l}\text { gi|925216718:81008935- } \\
81010247 \text { (NC_027312.1) }\end{array}$ \\
\hline
\end{tabular}

Consensus sequences to each of the nine cis-elements are given in Additional file 4

Genbank accession \# gives the complete genome sequences spanning the miRNA genes analysed 
The initial screening to identify DE miRNAs was carried out in materials from the latest time point post challenge (week 4 poc). It would therefore be expected that the majority of the miRNAs identified would be those involved in preventing pathological inflammation and tissue damage. Since we did not include earlier time points in the initial screening for DE miRNAs, we cannot rule out that other miRNAs are important regulators early in the infection. The role of such early responding miRNAs could be to promote an immune response. The decreased expression at the early time points of a few DE miRNAs identified in this study, e.g. the mature miRNAs from the miRNA 21 family (Fig. 4), could indicate that they may have such a role where they contribute to promote the early immune response. The downregulation at the early time points in the SAV2-i1 group of the mature miRNAs from the miRNA 21 family (Fig. 4) would be expected to contribute to an immediate increase in the immune response as downregulation of the miRNAs would lead to a proportional downregulation of the translational repression of the predicted target gene IRF3 (Table 2). The downregulation of another miRNA, ssa-miR-734-3p, was detected in the DESeq2 analysis, but could not be validated by RT-qPCR in our study (Table 1). However, if this miRNA is downregulated in the very early phase of infection this would also lead to an increased immune response as it was predicted to target viperine and interferon gamma (Table 2).

Analysis of the genomic sequences spanning the DE miRNA genes revealed a high density of response elements that may bind transcription factors associated with an innate immune response. Similar findings have been reported by Schyt et al. [28] for the teleost specific miRNA 462/731-gene cluster analysed in rainbow trout. Other conserved miRNA genes, like miRNA-146, miRNA-181 and miRNA-155 are also known to be INF-regulated in vertebrates with increased expression upon stimulation [11]. If the expression of the DE miRNAs identified in our study is enhanced by binding transcription factors activated by the immune response, this means that many of the DE miRNAs are the effector molecules participating in negative feedback loops. A recent study of miR-731-5p in Japanese flounder [44] demonstrated such a negative feedback where miR-731-5p was shown to target the transcription factor IRF7. The analyses of target genes in our study showed that, not only was ssa-miR-731-5p predicted to target the salmon ortholog of IRF7, but it was also predicted to target the ATP-dependent RNA helicase DHX58 (RIG-I-like 3). The RIG-I-like receptors are believed to be upstream activators of IRF7 [39]. Targeting not only IRF7, but also the upstream activator of IRF7, an increased expression of ssa-miR-731-5p would, as described in Zhang et al. [44], negatively regulate the immune response.

Together, the target gene predictions and the analysis of upstream genome sequences of the miRNA genes suggest that many of the DE miRNAs are important participants of the immune system gene pathways and some may act in negative feedback loops to maintain immune homeostasis. However, as demonstrated in our study, the expression of these DE miRNAs may differ depending on what kind of virus subtype that causes the immune response. Even virus infection caused by virus isolates belonging to the same subtype (SAV3-i4 and SAV3-i6) resulted in significant differences in expression of most of the DE miRNAs.

\section{Different expression patterns of the DE miRNAs may help explain differences in mortality}

The high expression at the late time point and the predicted target genes suggest that the ten miRNA (eight of these shown in Fig. 3) may act to prevent excess inflammation. The expression of these miRNAs (ssa-miR-462a$5 p$ and 3p, ssa-miR-731-5p and 3p, ssa-miR-146a-3p, ssa-miR-146b-5p, ssa-miR223-5p, ssa-miR-155-5p, ssamiR-181c-5p and ssa-miR7132-3p) were higher in the fish infected with SAV3-i6 (Fig. 3, Additional file 3) than in the other SAV3 isolate (SAV3-i4) at week 4 poc. This observation is interesting as Taksdal et al. [32] reported that there was a difference in mortality between the two isolates of SAV3 with a higher mortality in the SAV3-i4 group than in the SAV3-i6 group that could not be explained by their results. A higher expression of the ten DE miRNAs in the SAV3-i6 group than in the SAV3-i4 group could lead to a more pronounced down regulation of the inflammatory process in the SAV3-i6 group. The effect of this could be less pathological inflammation in the cardiac tissue in the following weeks that might result in a reduced mortality in the SAV3-i6 group compared to the SAV3-i4 group. The observation that ssa-miR-2188-3p has a significantly lower expression in the SAV3-i4 group than in the SAV3-i6 group (Fig. 4) could also contribute to a higher mortality in the SAV3i4 group. The two predicted targets of this miRNA promote inflammatory response and cell death (Table 2). Thus, a prolonged high expression of these predicted target genes would not benefit the host. The observed differences in expression of DE miRNAs between the SAV3-i4 and SAV3-i6 group are therefore in agreement with, and offer an explanation to, the observed differences in mortality between fish infected with these isolates of SAV3 subtype.

Fish challenged with SAV2-i1 was reported with a significantly lower mortality than those challenged with the two SAV3 isolates [32]. The SAV2-i1 group did, like the SAV3-i6 group, show a significantly higher expression at the latest time point in some miRNAs compared to the SAV3-i4 group (ssa-miR462a-5p, ssa-miR155-5p and ssa-miR-7132-3p, Fig. 3). However, in other miRNAs they revealed similar 
expression levels as those from the SAV3-i4 group, and comparing the SAV2-i1 group to the SAV3-i6 group all ten miRNAs (Fig. 3) showed a much lower expression in the SAV2-i1 group. The miRNA expression at the late time point in infection (week 4 poc) in these miRNAs could therefore not explain a mortality rate that was lower in the group infected by SAV2-i1 than in both of the groups infected with the SAV3 subtypes (SAV3-i6 and SAV3-i4). However, the expression of other miRNAs at the early time points may offer an explanation to these differences in mortality rate. There was a decreased expression in the miRNAs from the miRNA 21 family at week 2 and 3 poc in the SAV2-i1 group (Fig. 4). In contrast, there was an increase in expression across the same time points in the groups challenged with both isolates from the SAV3 subtype. These differences in expression, a reduction of miRNAs from the miRNA 21 family in the SAV2-i1 group versus an increase of these miRNAs in both of the SAV3 groups would lead to a faster and much more pronounced downregulation of the negative repression of the target gene in the SAV2-i1 group. The predicted target gene is IRF3, a constitutively expressed key activator of the innate immune system [52]. Thus, the differences in miRNA 21 family expressions could contribute to a faster and more effective early immune response in fish infected by SAV2-i1 and lead to a lower mortality in this group.

Although the observed differences in expression between DE miRNAs may offer some explanations to differences in virulence and mortality observed in fish infected by different SAV isolates they rely on the correctness of the target gene predictions. Thus, an obvious way forward would be to validate the target genes of the identified DE miRNAs and further explore the miRNAtarget gene interactions by experimental approaches.

\section{Conclusion}

This is the first miRNA profiling study in Atlantic salmon that has identified and characterized cellular miRNAs with modulated expression following virus infection indicating that they are important participants in the virus-host interaction. The target gene predictions and analysis of upstream genome sequences suggests that many of the miRNAs may regulate innate immune responses as effector molecules in negative feedback loops. Our findings represent a first step in exploring and suggesting a role for Atlantic salmon miRNAs in virus-host interactions. Further functional studies will help to disclose the particular role of these miRNA genes, and may contribute more knowledge on how these miRNAs act in concert with other regulator molecules to fine-tune the innate immune system responses.

\section{Materials and Methods Materials}

A challenge trial was carried out where healthy Atlantic salmon (smolt) were exposed to SAV by cohabitating with salmon shedders injected with virus (carrier fish). The cohabitant challenge experiment and sampling of tissue is described in detail in Taksdal et al. [32]. In short, the fish used for the challenge experiment was unvaccinated, clinically healthy Atlantic salmon from VESO Vikane hatchery. Health conditions was also confirmed by examining ten fish for common fish viruses. They all tested negative for piscine myocarditis virus (PMCV), piscine reovirus (PRV), infectious pancreatic necrosis virus (IPNV) and SAV. The fish was challenged with $3 \mathrm{SAV}$-isolates derived from independent outbreaks of Pancreas Disease in Norwegian fish farms, either marine SAV2 (SAV2-i1) or one of two isolates of SAV3; SAV3-i4 and SAV3-i6 [32].

Cardiac tissue samples were collected from the cohabitating (non-injected) fish. Co-habitant samples were collected at four time points; at the initiation of the experiment (controls), at week one, two, three and four post onset of the challenge experiment. Eight fish collected at the initiation of the experiment were used as healthy controls, while nine fish, three from each SAV group was collected at week 1 poc. Nine fish challenged with either SAV2-i1, SAV3-i4 or SAV3-i6 were sampled at week two, three and four poc. Together, cardiac tissue from 98 fish was sampled. All samples from controls, week one, two, three and four poc were analysed to measure viral load by RT-qPCR. All samples from week 1 poc, four samples from fish challenged with SAV2-i1 and one sample from fish challenged with SAV3-i4 at week 2 poc were SAV negative and were removed from further analysis of miRNA expression. The samples from the remaining individuals at week 2 poc, and all fish from week 3 and 4 poc, tested positive for SAV $(n=78)$. The eight control samples and the SAV positive samples from other time points (total of 84 samples) were all included in our study of miRNA expression (RT-qPCR of miRNA).

Three healthy controls and three samples collected at week 4 poc from the SAV3-i4 group were used for deep sequencing and DESeq2 analysis. Fish infected with SAV3-i4 were choosen as this was the SAV isolate associated with the highest mortality rate [32]. The late time point (week 4 poc) was choosen as the virus loads were high and $100 \%$ of fish from all three groups were infected at this time point. The experimental study was approved by the National Research Authority in Norway (NARA). All salmon used for sampling in the experiment were euthanized according to standard protocols approved by the Norwegian Food Safety Authorities prior to sampling. 


\section{Methods}

\section{Small RNA isolation}

Sampling of cardiac tissue was carried out as described in Taksdal et al. [32]. Samples were fixed in RNA later (Life technologies, Carlsbad, USA) immediately after sampling. Total RNA was isolated from each of the samples by use of the mirVana miRNA isolation kit (Ambion, Life Technologies, Carlsbad, CA, USA) following the manufacturer's protocol. The RNA concentration and purity was determined using Nanodrop spectrophotometer (Thermo Fisher Scientific, WI, USA) following the manufacturer's protocol. The concentration of total RNA in samples ranged from 21-255 ng/ $\mu$ l (total volume $100 \mu \mathrm{l}$ ) and with A260/280 ratios above 1,9. The integrity of the RNA in samples used for deep sequencing was analyzed using the Agilent Bioanalyzer system (Agilent, CA, USA). The RIN values were from 6.8 to 10 (Additional file 1).

\section{RT-qPCR detection of SAV}

SAV in the cardiac samples was detected by RT-qPCR with a Qiagen Onestep RT-PCR kit using TaqMan assay with primers and probe targeting the nsP1 gene as described in Hodeland and Endresen [53]. Viral load (Ct values) was measured by RT-qPCR in all samples from controls, week one, two, three and four poc $(n=98)$.

\section{Library construction, deep sequencing and quantitative analysis}

The library construction was performed at the Norwegian Genomics Consortium's genomics core facility. The Illumina TruSeq Small RNA Library Preparation Kit (Illumina, San Diego, USA) was used in the preparation of the libraries as described by the manufacturer with 1 ug total RNA input. After adapter ligation and cDNA synthesis the products were purified on a gel and the fractions between 145 and 160 bp were used for sequencing. The small RNA libraries constructed from six samples (three from controls and three from the SAV3-i4 group sampled at week 4 post onset of challenge experiment) were successfully subjected to next generation sequencing using Illumina Genome Analyzer IIx sequencing platform as described in Andreassen et al. [25]. Reads quality were assessed using FastQC toolkit (http://www.bioinformatics.babraham.ac.uk/projects/fastqc). Cutadapt [54] was used for trimming of adapter sequences from raw sequence reads and removal of adapter-only sequences (5'TGGAATTCTCG GGTGCCAAGGAACTCCAGTCAC 3'). Finally, an additional filtering of reads outside of 18-25 nucleotide range was applied on all samples. All deep sequencing samples have been submitted to the NCBI Sequence Read Archive database (SRA) and accession numbers are given in Additional file 1.
Next, the reads from each of the six samples were aligned to a set of miRNAs that consisted of all known Salmo salar mature miRNAs [25, 26] using Novoalign (http://www.novocraft.com/products/novoalign/). Custom made scripts were used to report number of successfully assigned reads to each miRNA. The reads mapping with edit distance 1 or less to the mature reference sequences were considered true mature miRNAs. Differentially expressed miRNAs were identified with DESeq2 package [33]. Rows with less than 2 reads for each condition were discarded from the analysis. A threshold of $\mathrm{p}$-adjusted value $<0.1$ (adjusted according to Benjamini-Hochberg procedure) was applied to report differentially expressed miRNAs. The two groups compared were controls (three samples) and SAV3-i4 infected individuals (three samples) from week 4 poc.

\section{cDNA synthesis and RT-qPCR of miRNAs}

The miScript assays were used for cDNA synthesis (miScript II RT Kit) and qPCR (miScript SYBR Green PCR kit) as described by the manufacturer (Qiagen, Hilden, Germany). The reverse primer (universal primer) was provided with the miScript qPCR kit while the forward primer was custom designed and specific to each of the mature miRNA gene assays. The sequence of the forward primers were designed based on the mature sequence of each of the miRNA genes to be amplified [25]. All forward primers were purchased from Sigma Aldridge. They were purified by desalt only and provided as liquid solution of $100 \mu \mathrm{M}$. The primers were diluted to $10 \mu \mathrm{M}$ for use in each of the qPCR assays. All forward primer sequences are given in Additional file 2. The qPCR analysis was run on an Mx3000p (Stratagene, Agilent Technologies, USA). The qPCR reaction mixture consisted of $12.5 \mu \mathrm{L} \mathrm{2x}$ Quantitec Syber Green Master Mix, $2.5 \mu \mathrm{L} \mathrm{10x} \mathrm{miScript} \mathrm{Universal} \mathrm{Primer,} 2.5 \mu \mathrm{L}$ of $10 \mu \mathrm{M}$ forward miRNA gene specific primer, $5 \mu \mathrm{L}$ Rnase free water, and $2.5 \mu \mathrm{L} \mathrm{cDNA}$ (template). Amplification was performed in 96-well plates. The following program was used: one thermal cycle at $95{ }^{\circ} \mathrm{C}$ for 15 min followed by 40 cycles of $94{ }^{\circ} \mathrm{C}$ for $15 \mathrm{sec}, 55{ }^{\circ} \mathrm{C}$ for $30 \mathrm{sec}$ and $70{ }^{\circ} \mathrm{C}$ for $30 \mathrm{sec}$. The cybergreen assay module was used for qPCR analysis. This module includes a final melting point analysis that follows the 40 cycles of quantitative PCR. A manual inspection of the plots from the melting point analysis of all miRNA gene assays tested was carried out to verify that forward primers were specific (data not shown).

In all cases of measurements of miRNA expression by RT-qPCR, the samples that were compared were run in the same set-up (within run measurements). Three miRNAs ssa-miR-25-3p, ssa-miR-455-5p and ssa-miR-17-5p were used as reference genes [27]. Results (Ct-values) of target miRNAs were normalized by use of the geometric 
mean from the measurements of the three reference genes [55]. The relative increase in expression in target tissue of each miRNA was calculated using the principle of the $\Delta \Delta$ Ct-method [35]. Applying this method the average relative difference in target tissue was calculated as the difference between mean normalized $\mathrm{Ct}$ from target tissue and mean normalized $\mathrm{Ct}$ from reference tissue. To test whether the relative differences in expression revealed by the $\Delta \Delta \mathrm{Ct}$-method between controls and SAV infected groups was significant we performed MannWhitney tests using the statistical package SPSS. Likewise, Mann-Whitney tests were also used to test for significant difference in expression of miRNAs at the same time point between the three SAV groups. P-values were adjusted by use of the Benjamini-Hochberg procedure taking into account there were 153 comparisons between SAV groups at different time points (P-adjusted values equal to a 0.05 significance level). Test for correlation between estimates of relative differences by DESeq 2 and by RT-qPCR of the 17 mature miRNAs analysed by both methods was carried out by use of Spearman's nonparametric test for correlation (SPSS package).

\section{miRNA target gene predictions}

The mature sequences from the DE miRNAs were used as input in the target gene prediction analysis. The 3'UTRs from two sets of genes were used as input for target genes. One set was genes reported as responding to SAV infection and associated with immune response or response to viral infection $[38,39]$. In addition, the Atlantic salmon orthologs to some genes that are key regulators of immune responses and reported in other species as targets of the same miRNAs as those identified in our study were included in this set of genes [40-45]. Applying these selection criteria based on prior knowledge about their relevance to SAV infection and immune response (knowledge based approach) a total of 50 genes were analysed to detect target site matches (Additional file 4). The other set of genes used as input were 3'UTRs from all Atlantic salmon mRNA transcripts in the Refseq database in Genbank (https:// www.ncbi.nlm.nih.gov/). This holistic approach could possibly identify target genes among immune network genes not previously known to respond to SAV infection.

The in silico analysis to identify target genes were carried out by use of four different target gene prediction tools; RNAhybrid, TargetSpy, PITA and Miranda. RNAhybrid analysis was performed with conditions helix constraint 2-8 and no G:U in seed allowing only target genes that had perfect "seed" matches to be detected [36]. Minimum free energy threshold for RNA hybrids was set to $-18 \mathrm{kcal} / \mathrm{mol}$ to retrieve results (target site matches) from RNA hybrids that had a high stability [56]. RNA hybrid was used to generate the figure in
Additional file 5. The target site analysis with the tools TargetSpy, PITA and Miranda was carried out applying default settings using the sRNAtoolbox (http://bioinfo5.ugr.es/srnatoolbox/mirconstarget/)[37].

\section{Functional motif analysis of the genome sequences spanning the DE miRNA genes}

The upstream genome sequences of all DE miRNA genes were retrieved by using precursor sequences [25] as input in BLASTn searches against the current version of the Salmo salar genome sequence in Genbank (Genbank \# GCF_000233375.1). Several of the mature miRNAs could originate from duplicated miRNA genes. Thus, the total number of miRNA genes analysed was 24. One thousand base-pairs of the upstream sequence and 200 base-pairs of the downstream sequence from the mature $5 p$ sequences of each the DE miRNA genes were analysed regarding presence of conserved response elements known to bind key transcription factors from the innate immune system gene network. Consensus sequences of vertebrate response elements were retrieved from the MotifMap database (http://motifmap.ics.uci.edu/). In addition, Salmonid specific motifs were retrieved from Robertsen [57] and Schyth et al. [28]. The consensus sequences of the nine response elements used for upstream genome analysis are given in Additional file 7. The consensus sequences of conserved immune related response elements (ISRE-IRF, NF-kappaB and ETS2), the TATA-box consensus sequence as well as the response elements GAS and PU1 characterized in a study of the rainbow miRNA 462/731 gene cluster [28] are all detected with the general consensus sequences used in our genome sequence analysis. ISRE and NFkap$\mathrm{paB}$ motifs in zebrafish are also detected using these motifs $[58,59]$ indicating that the consensus sequence applied detect these motifs in teleost fish (including Atlantic salmon). Presence of any motif was detected by use of Sequencher software (Gene Codes Corporation, Michigan, USA).

\section{Additional files}

Additional file 1: shows descriptive data from deep sequencing of six samples including number of size filtered and adapter trimmed reads, and reads mapped as ssa-miRNAs in each sample. (XLSX $17 \mathrm{~kb}$ )

Additional file 2: shows all primer sequences of primers used in the RT-qPCR along with R-square values and efficiency measurements. (XLSX $12 \mathrm{~kb}$ )

Additional file 3: gives a complete overview of all results from RT-qPCR analysis showing the magnitude of change in each SAV-group compared to controls at each of the time points along with measurements of significance (adjusted p-values). All results from comparing different SAV groups within same time points are also summarized in Additional file 2. (XLSX $20 \mathrm{~kb})$ 
Additional file 4: shows all SAV responsive immune network genes that were included in the target gene analysis against the DE miRNAs (knowledge based approach. (XLSX $15 \mathrm{~kb}$ )

Additional file 5: shows the predicted RNA hybrid formed between ssa-miR-21b-3p and the nucleotides 805-827 in the IRF3 transcript's 3'UTR. (DOCX $16 \mathrm{~kb}$ )

Additional file 6: shows complete results from target gene predictions using all Atlantic salmon transcripts in Refseq, Genbank as input in the in silico analysis (holistic approach). (XLSX $220 \mathrm{~kb}$ )

Additional file 7: gives the consensus sequences of all promotor response elements included in the analysis of upstream miRNA gene sequences. (XLSX $11 \mathrm{~kb}$ )

\section{Abbreviations}

DE miRNAs: differentially expressed miRNAs; miRNA: microRNA; poc: post onset of challenge experiment; SAV2-i1: salmonid alphavirus subtype 2 isolate 1; SAV3-i4: salmonid alphavirus subtype 3 isolate 4; SAV3-i6: salmonid alphavirus subtype 3 isolate 6

\section{Acknowledgements}

We would like to thank Jonathan Kans for help with retrieving 3'UTRs from mRNA sequences in Refseq, Genbank.

\section{Funding}

This study was financially supported by Norwegian Research Council grant 254849/E40. The Norwegian Research Council had no role in the design of the study, the collection, analysis, and interpretation of data or in the writing of the manuscript.

\section{Availability of data and materials}

All data generated during the current study are available in this published article and its supplementary information files. The datasets from deep sequencing are available from Genbank accession number SRP048613, see Additional file 1 for SRA database accession numbers to individual samples.

\section{Authors' contributions}

RA conceived and coordinated the study. He worked on all aspects of the study including extraction of total RNA, cDNA synthesis, RT-qPCR, the bioinformatics analyses and drafted the manuscript. NTW carried out major part of in silico analyses including BLAST analyses, predictions of target genes and promotor searches. IØE performed major part of the CDNA synthesis, carried out major part of RT-qPCR and analysed the RT-qPCR results. OA performed major part of the processing of the deep sequencing data and DESeq2 analysis. HS contributed all challenge materials and performed RT-qPCR measurements of viral loads. BH contributed in design of the study and participated in preparation of the manuscript. All co-authors participated in preparation of the final manuscript that was read and approved by all authors.

\section{Competing interests}

The authors declare that they have no competing interests.

\section{Consent for publication}

Not applicable.

\section{Ethics approval}

Bath challenges with SAV and sacrifice procedure was approved by the official ethics board FOTS (forsøksdyrutvalgets tilsyns- og søknadssystem). The bath challenges were conducted in the confined and controlled isolation facilities of VESO Vikane hatchery. Dissection of fish and sampling of materials was performed in agreement with the provisions enforced by the Norwegian Animal Research Authority.

\section{Publisher's Note}

Springer Nature remains neutral with regard to jurisdictional claims in published maps and institutional affiliations.

\section{Author details}

'Department of Pharmacy and Biomedical and Laboratory Sciences, Faculty of Health Sciences, Oslo and Akershus University College of Applied
Sciences, Pilestredet 50, N-0130 Oslo, Norway. ${ }^{2}$ Bioinformatics Core Facility, Department of Core Facilities, Institute of Cancer Research, Radium hospital, part of Oslo University Hospital, Oslo, Norway. ${ }^{3}$ Norwegian Veterinary Institute, PB 750 Sentrum, N-106 Oslo, Norway. ${ }^{4}$ Department of Basic Sciences and Aquatic Medicine, School of Veterinary Medicine, Norwegian University of Life Sciences, Ullevålsveien 72, 0454 Oslo, Norway.

Received: 29 October 2016 Accepted: 27 April 2017

Published online: 04 May 2017

\section{References}

1. Bartel DP. MicroRNAs: genomics, biogenesis, mechanism, and function. Cell. 2004;116(2):281-97.

2. Chekulaeva M, Filipowicz W. Mechanisms of miRNA-mediated posttranscriptional regulation in animal cells. Curr Opin Cell Biol. 2009;21(3):452-60.

3. Winter J, Jung S, Keller S, Gregory Rl, Diederichs S. Many roads to maturity: microRNA biogenesis pathways and their regulation. Nat Cell Biol. 2009; 11(3):228-34.

4. Griffiths-Jones S, Grocock RJ, van Dongen S, Bateman A, Enright AJ. miRBase: microRNA sequences, targets and gene nomenclature. Nucleic Acids Res. 2006;34(Database issue):D140-144.

5. Pasquinelli $A E$, Reinhart BJ, Slack F, Martindale $M Q$, Kuroda Ml, Maller B, Hayward DC, Ball EE, Degnan B, Muller P, et al. Conservation of the sequence and temporal expression of let-7 heterochronic regulatory RNA. Nature. 2000;408(6808):86-9.

6. Bushati N, Cohen SM. microRNA functions. Annu Rev Cell Dev Biol. 2007:23: 175-205.

7. He L, Hannon GJ. MicroRNAs: small RNAs with a big role in gene regulation. Nat Rev Genet. 2004;5(7):522-31.

8. Lagos-Quintana M, Rauhut R, Yalcin A, Meyer J, Lendeckel W, Tuschl T. Identification of tissue-specific microRNAs from mouse. Curr Biol. 2002;12(9): 735-9.

9. Stefani G, Slack FJ. Small non-coding RNAs in animal development. Nat Rev Mol Cell Biol. 2008;9(3):219-30.

10. Sonkoly E, Stahle M, Pivarcsi A. MicroRNAs and immunity: novel players in the regulation of normal immune function and inflammation. Semin Cancer Biol. 2008;18(2):131-40.

11. Forster SC, Tate MD, Hertzog PJ. MicroRNA as Type I Interferon-Regulated Transcripts and Modulators of the Innate Immune Response. Front Immunol. 2015;6:334.

12. Guo YE, Steitz JA. Virus meets host microRNA: the destroyer, the booster, the hijacker. Mol Cell Biol. 2014;34(20):3780-7.

13. Skalsky RL, Cullen BR. Viruses, microRNAs, and host interactions. Annu Rev Microbiol. 2010;64:123-41.

14. Swaminathan G, Martin-Garcia J, Navas-Martin S. RNA viruses and microRNAs: challenging discoveries for the 21st century. Physiol Genomics. 2013;45(22):1035-48.

15. Li Y, Shi X. MicroRNAs in the regulation of TLR and RIG-I pathways. Cell Mol Immunol. 2013;10(1):65-71.

16. Cullen BR. MicroRNAs as mediators of viral evasion of the immune system. Nat Immunol. 2013;14(3):205-10.

17. Song L, Liu H, Gao S, Jiang W, Huang W. Cellular microRNAs inhibit replication of the H1N1 influenza A virus in infected cells. J Virol. 2010; 84(17):8849-60.

18. Trobaugh DW, Gardner CL, Sun C, Haddow AD, Wang E, Chapnik E, Mildner A, Weaver SC, Ryman KD, Klimstra WB. RNA viruses can hijack vertebrate microRNAs to suppress innate immunity. Nature. 2014;506(7487):245-8.

19. Song H, Wang Q, Guo Y, Liu S, Song R, Gao X, Dai L, Li B, Zhang D, Cheng J. Microarray analysis of microRNA expression in peripheral blood mononuclear cells of critically ill patients with influenza A (H1N1). BMC Infect Dis. 2013;13:257.

20. Janssen HL, Reesink HW, Lawitz EJ, Zeuzem S, Rodriguez-Torres M, Patel K, van der Meer AJ, Patick AK, Chen A, Zhou Y, et al. Treatment of HCV infection by targeting microRNA. N Engl J Med. 2013;368(18):1685-94.

21. Zhang BC, Zhang J, Sun L. In-depth profiling and analysis of host and viral microRNAs in Japanese flounder (Paralichthys olivaceus) infected with megalocytivirus reveal involvement of microRNAs in host-virus interaction in teleost fish. BMC Genomics. 2014;15:878.

22. Guo C, Cui H, Ni S, Yan Y, Qin Q. Comprehensive identification and profiling of host miRNAs in response to Singapore grouper iridovirus (SGIV) infection in grouper (Epinephelus coioides). Dev Comp Immunol. 2015;52(2):226-35. 
23. Najib A, Kim MS, Choi SH, Kang YJ, Kim KH. Changes in microRNAs expression profile of olive flounder (Paralichthys olivaceus) in response to viral hemorrhagic septicemia virus (VHSV) infection. Fish Shellfish Immunol. 2016:51:384-91.

24. Bela-ong DB, Schyth BD, Zou J, Secombes CJ, Lorenzen N. Involvement of two microRNAs in the early immune response to DNA vaccination against a fish rhabdovirus. Vaccine. 2015;33(28):3215-22.

25. Andreassen R, Worren MM, Hoyheim B. Discovery and characterization of miRNA genes in Atlantic salmon (Salmo salar) by use of a deep sequencing approach. BMC Genomics. 2013;14:482.

26. Bekaert M, Lowe NR, Bishop SC, Bron JE, Taggart JB, Houston RD. Sequencing and characterisation of an extensive Atlantic salmon (Salmo salar L.) microRNA repertoire. PLoS One. 2013;8(7):e70136.

27. Johansen I, Andreassen R. Validation of miRNA genes suitable as reference genes in $\mathrm{PPCR}$ analyses of miRNA gene expression in Atlantic salmon (Salmo salar). BMC Res Notes. 2014;8:945.

28. Schyth BD, Bela-Ong DB, Jalali SA, Kristensen LB, Einer-Jensen K, Pedersen FS, Lorenzen N. Two Virus-Induced MicroRNAs Known Only from Teleost Fishes Are Orthologues of MicroRNAs Involved in Cell Cycle Control in Humans. PLoS One. 2015;10(7), e0132434.

29. McLoughlin MF, Graham DA. Alphavirus infections in salmonids-a review. J Fish Dis. 2007;30(9):511-31.

30. Fringuelli E, Rowley HM, Wilson JC, Hunter R, Rodger H, Graham DA Phylogenetic analyses and molecular epidemiology of European salmonid alphaviruses (SAV) based on partial E2 and nsP3 gene nucleotide sequences. J Fish Dis. 2008;31(11):811-23.

31. Jansen MD, Bang Jensen B, McLoughlin MF, Rodger HD, Taksdal T, Sindre H, Graham DA, Lillehaug A. The epidemiology of pancreas disease in salmonid aquaculture: a summary of the current state of knowledge. J Fish Dis. 2017; 40(1):141-55.

32. Taksdal T, Jensen BB, Bockerman I, McLoughlin MF, Hjortaas MJ, Ramstad A, Sindre H. Mortality and weight loss of Atlantic salmon, Salmon salar L., experimentally infected with salmonid alphavirus subtype 2 and subtype 3 isolates from Norway. J Fish Dis. 2015;38(12):1047-61.

33. Anders $\mathrm{S}$, Huber W. Differential expression analysis for sequence count data. Genome Biol. 2010;11(10):R106.

34. Guo L, Zhao Y, Zhang H, Yang S, Chen F. Integrated evolutionary analysis of human miRNA gene clusters and families implicates evolutionary relationships. Gene. 2014;534(1):24-32.

35. Schmittgen TD, Livak KJ. Analyzing real-time PCR data by the comparative C(T) method. Nat Protoc. 2008;3(6):1101-8.

36. Rehmsmeier M, Steffen $P$, Hochsmann M, Giegerich R. Fast and effective prediction of microRNA/target duplexes. RNA. 2004;10(10):1507-17.

37. Rueda A, Barturen G, Lebron R, Gomez-Martin C, Alganza A, Oliver JL, Hackenberg M. sRNAtoolbox: an integrated collection of small RNA research tools. Nucleic Acids Res. 2015;43(W1):W467-473.

38. Johansen LH, Thim HL, Jorgensen SM, Afanasyev S, Strandskog G, Taksdal T, Fremmerlid K, McLoughlin M, Jorgensen JB, Krasnov A. Comparison of transcriptomic responses to pancreas disease (PD) and heart and skeletal muscle inflammation (HSMI) in heart of Atlantic salmon (Salmo salar L). Fish Shellfish Immunol. 2015;46(2):612-23.

39. Xu C, Evensen O, Mweemba Munang'andu H. De Novo Transcriptome Analysis Shows That SAV-3 Infection Upregulates Pattern Recognition Receptors of the Endosomal Toll-Like and RIG-I-Like Receptor Signaling Pathways in Macrophage/Dendritic Like TO-Cells. Viruses. 2016;8(4):114.

40. Sun B, Skjaeveland I, Svingerud T, Zou J, Robertsen, B: Antiviral activity of salmonid gamma interferon against infectious pancreatic necrosis virus and salmonid alphavirus and its dependency on type I interferon. J Virol 2011; 85(17):9188-98.

41. Hou J, Wang P, Lin L, Liu X, Ma F, An H, Wang Z, Cao X. MicroRNA-146a feedback inhibits RIG-I-dependent Type I IFN production in macrophages by targeting TRAF6, IRAK1, and IRAK2. J Immunol. 2009;183(3):2150-8.

42. Wang P, Hou J, Lin L, Wang C, Liu X, Li D, Ma F, Wang Z, Cao X. Inducible microRNA-155 feedback promotes type I IFN signaling in antiviral innate immunity by targeting suppressor of cytokine signaling 1. J Immunol. 2010; 185(10):6226-33.

43. Aziz F. The emerging role of miR-223 as novel potential diagnostic and therapeutic target for inflammatory disorders. Cell Immunol. 2016;303:1-6.

44. Zhang BC, Zhou ZJ, Sun L. pol-miR-731, a teleost miRNA upregulated by megalocytivirus, negatively regulates virus-induced type I interferon response, apoptosis, and cell cycle arrest. Sci Rep. 2016;6:28354.
45. Taganov KD, Boldin MP, Chang KJ, Baltimore D. NF-kappaB-dependent induction of microRNA miR-146, an inhibitor targeted to signaling proteins of innate immune responses. Proc Natl Acad Sci U S A. 2006; 103(33):12481-6.

46. Witkos TM, Koscianska E, Krzyzosiak WJ. Practical Aspects of microRNA Target Prediction. Curr Mol Med. 2011;11(2):93-109.

47. Long YS, Deng GF, Sun XS, Yi YH, Su T, Zhao QH, Liao WP. Identification of the transcriptional promoters in the proximal regions of human microRNA genes. Mol Biol Rep. 2011;38(6):4153-7.

48. Quinn SR, Mangan NE, Caffrey BE, Gantier MP, Williams BR, Hertzog PJ, McCoy CE, O'Neill LA. The role of Ets2 transcription factor in the induction of microRNA-155 (miR-155) by lipopolysaccharide and its targeting by interleukin-10. J Biol Chem. 2014;289(7):4316-25.

49. Carpenter S, Ricci EP, Mercier BC, Moore MJ, Fitzgerald KA. Posttranscriptional regulation of gene expression in innate immunity. Nat Rev Immunol. 2014;14(6):361-76.

50. Luo X, Ranade K, Talker R, Jallal B, Shen N, Yao Y. microRNA-mediated regulation of innate immune response in rheumatic diseases. Arthritis Res Ther. 2013;15(2):210.

51. Haneklaus M, Gerlic M, O'Neill LA, Masters SL. miR-223: infection, inflammation and cancer. J Intern Med. 2013;274(3):215-26.

52. Honda K, Taniguchi T. IRFs: master regulators of signalling by Toll-like receptors and cytosolic pattern-recognition receptors. Nat Rev Immunol. 2006;6(9):644-58.

53. Hodneland K, Endresen C. Sensitive and specific detection of Salmonid alphavirus using real-time PCR (TaqMan). J Virol Methods. 2006;131(2):184-92.

54. Martin M. Cutadapt removes adapter sequences from high-throughput sequence reads. EMBnet J. 2011;17:1-3.

55. Vandesompele J, De Preter K, Pattyn F, Poppe B, Van Roy N, De Paepe A, Speleman F. Accurate normalization of real-time quantitative RT-PCR data by geometric averaging of multiple internal control genes. Genome Biol. 2002;3(7):1-11.

56. Peterson SM, Thompson JA, Ufkin ML, Sathyanarayana $\mathrm{P}$, Liaw L, Congdon CB. Common features of microRNA target prediction tools. Front Genet. 2014,5:23.

57. Robertsen B. Expression of interferon and interferon-induced genes in salmonids in response to virus infection, interferon-inducing compounds and vaccination. Fish Shellfish Immunol. 2008;25(4):351-7.

58. Feng $H$, Zhang YB, Zhang QM, Li Z, Zhang QY, Gui JF. Zebrafish IRFI regulates IFN antiviral response through binding to IFNvarphi1 and IFNvarphi3 promoters downstream of MyD88 signaling. J Immunol. 2015; 194(3):1225-38.

59. Correa RG, Tergaonkar V, Ng JK, Dubova I, Izpisua-Belmonte JC, Verma IM. Characterization of NF-kappa B/I kappa B proteins in zebra fish and their involvement in notochord development. Mol Cell Biol. 2004;24(12):5257-68.

\section{Submit your next manuscript to BioMed Central and we will help you at every step:}

- We accept pre-submission inquiries

- Our selector tool helps you to find the most relevant journal

- We provide round the clock customer support

- Convenient online submission

- Thorough peer review

- Inclusion in PubMed and all major indexing services

- Maximum visibility for your research

Submit your manuscript at www.biomedcentral.com/submit 